\title{
Nd isotope constraints on ocean circulation, paleoclimate, and continental drainage during the Jurassic breakup of Pangea
}

\author{
Guillaume Dera $^{\mathrm{a}, *}$, Jonathan Prunier ${ }^{\mathrm{a}}$, Paul L. Smith ${ }^{\mathrm{b}}$, James W. Haggart ${ }^{\mathrm{b}, \mathrm{c}}$, Evgeny Popov ${ }^{\mathrm{d}}$, \\ Alexander Guzhov ${ }^{e}$, Mikhail Rogov ${ }^{\dagger}$, Dominique Delsate ${ }^{g}$, Detlev Thies ${ }^{h}$, Gilles Cuny', \\ Emmanuelle Pucéat', Guillaume Charbonnier', Germain Bayon'
}

\author{
a Laboratoire GET, CNRS UMR 5563, Université Paul Sabatier, OMP, 14 Avenue Edouard Belin, 31400 \\ Toulouse, France \\ b Department of Earth, Ocean and Atmospheric Sciences, University of British Columbia, 2207 Main Mall, \\ Vancouver, British Columbia V6T 1Z4, Canada \\ ${ }^{c}$ Geological Survey of Canada, 1500-605 Robson Street, Vancouver, British Columbia V6B 5J3, Canada \\ d Department of Palaeontology, Geological Faculty, Saratov State University, 83 Astrakhanskaya Str., 400012 \\ Saratov, Russia \\ e Paleontological Institute, Russian Academy of Sciences, 123 Profsoyuznaya ul., 117997 Moscow, Russia \\ ${ }^{\dagger}$ Geological Institute, Russian Academy of Sciences, 7 Pyzhevsky lane, 119017 Moscow, Russia \\ ${ }^{9}$ Muséum National d'Histoire Naturelle, 25 rue Munster, 2160 Luxembourg, Luxemburg \\ h Institut für Geologie, Leibniz Universität Hannover, Callinstr. 30, D-30167 Hannover, Germany \\ i The Natural History Museum of Denmark, Øster Voldgade 5-7, 1350 Copenhagen K, Denmark \\ j Laboratoire Biogéosciences, CNRS UMR 6282, Université de Bourgogne, 6 Bd Gabriel, 21000 Dijon, France \\ k Laboratoire IDES, CNRS UMR 8148, Université Paris Sud XI, 91405 Orsay, France \\ ' Ifremer, Unité de Recherche Géosciences Marines, 29280 Plouzané, France
}

*: Corresponding author : Guillaume Dera, email address : guillaume.dera@get.obs-mip.fr

\begin{abstract}
:
The breakup of Pangea and onset of growth of the Pacific plate led to several paleoenvironmental feedbacks, which radically affected paleoclimate and ocean chemistry during the Jurassic. Overall, this period was characterized by intense volcanic degassing from large igneous provinces and circumPanthalassan arcs, new oceanic circulation patterns, and changes in heat and humidity transports affecting continental weathering. Few studies, however, have attempted to unravel the global interactions linking these processes over the long-term. In this paper, we address this question by documenting the global changes in continental drainage and surface oceanic circulation for the whole Jurassic period. For this purpose, we present 53 new neodymium isotope values $\left(\varepsilon_{\mathrm{Nd}(t)}\right)$ measured on well-dated fossil fish teeth, ichthyosaur bones, phosphatized nodules, phosphatized ooids, and clastic sediments from Europe, western Russia, and North America.
\end{abstract}

Combined with an extensive compilation of published $\varepsilon_{\mathrm{Nd}(t)}$ data, our results show that the continental sources of $\mathrm{Nd}$ were very heterogeneous across the world. Volcanic inputs from a Jurassic equivalent

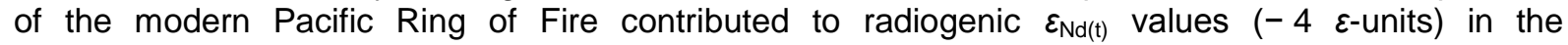
Panthalassa Ocean. For the Tethyan Ocean, the average surface seawater signal was less radiogenic in the equatorial region (-6.3), and gradually lower toward the epicontinental peri-Tethyan $(-7.4)$, 
western Russian (-7.4) and Euro-Boreal seas (-8.6). Different $\mathrm{Nd}$ sources contributed to this disparity, with radiogenic Nd influxes from westward Panthalassan currents or juvenile volcanic arcs in open oceanic domains, and substantial unradiogenic inputs from old Laurasian and Gondwanan shields for the NW Tethyan platforms. Overall, the $\varepsilon_{\mathrm{Nd}(t)}$ values of Euro-Boreal, peri-Tethyan, and western Russian waters varied quite similarly through time, in response to regional changes in oceanic circulation, paleoclimate, continental drainage, and volcanism. Three positive shifts in $\varepsilon_{\mathrm{Nd}(t)}$ values occurred successively in these epicontinental seas during the Pliensbachian, in the AalenianBathonian interval, and in the mid-Oxfordian. The first and third events are interpreted as regional incursions of warm surface radiogenic currents from low latitudes. The Aalenian-Bathonian shift seems linked to volcanic outbursts in the NW Tethys and/or circulation of deep currents resulting from extensional events in the Hispanic Corridor and reduced influences of boreal currents crossing the Viking Corridor. In contrast, the $\varepsilon_{\mathrm{Nd}(t)}$ signals decreased and remained very low $(<-8)$ during the global warming events of the Toarcian and Late Oxfordian - Early Tithonian intervals. In these greenhouse contexts, a latitudinal expansion of humid belts could have extended the drainage pathways toward boreal $\mathrm{Nd}$ sources of Precambrian age and increased the supply of very unradiogenic crustal-derived inputs to seawater. Finally, a brief negative $\varepsilon_{\mathrm{Nd}(t)}$ excursion recorded in parallel with regional drops in seawater temperature suggests that southward circulation of cold unradiogenic Arctic waters occurred in the NW Tethys in the Callovian - Early Oxfordian. All these results show that changes in surface oceanic circulation resulting from the Pangean breakup could have regionally impacted the evolution of seawater temperatures in the NW Tethys.

\section{Graphical abstract}

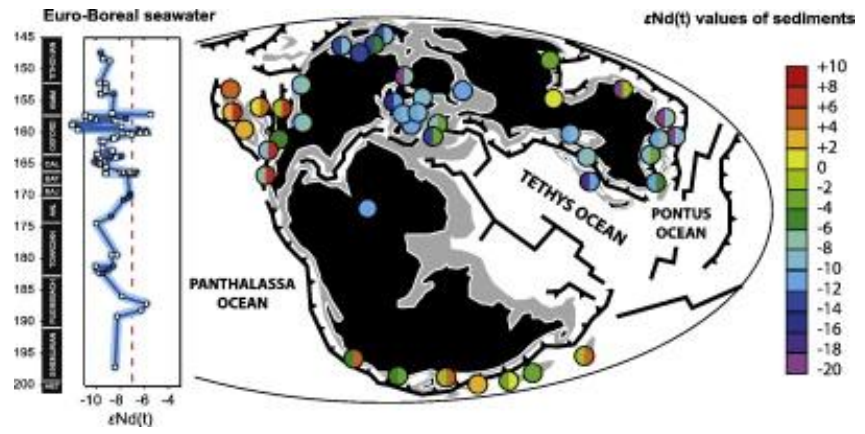

\section{Highlights}

The continental sources of $\mathrm{Nd}$ were heterogeneous during the Jurassic Numerous changes in the $\mathrm{Nd}$ isotope composition of oceans and sediments are recorded $>$ Changes reflect oceanic, climatic, and volcanic events related to the Pangean breakup 


\section{Introduction}

The Jurassic marked the onset of the Pangean breakup that led to our modern geography. Starting with crustal thinning and prominent flood basalt events in the Central Atlantic Magmatic Province and the Karoo-Ferrar area (Coffin and Eldhoom, 1992), this continental reorganization was governed foremost by an extensional regime, resulting in new marine connections between oceanic domains. In the Early Jurassic, this was reflected by the progressive openings of the Hispanic and Viking corridors (i.e., trans-Pangean and transLaurasian seaways linking the Tethyan domain to the Eastern Panthalassan and Arctic areas, respectively), which ultimately led to the formation of Caribbean and North Atlantic oceanic crusts (Figure 1) (Doré, 1991; Labails et al., 2010). Similarly, the latest Jurassic marked the development of a trans-Gondwanan strait, which evolved subsequently into the Indian Ocean (Alberti et al., 2012; Gaina et al., 2013). In contrast, the incipient growth of the Pacific plate in the Middle Jurassic triggered compressive movements, increasing subduction, terrane accretion, and arc volcanism all around the Panthalassa Ocean (Bartolini and Larson, 2001). The best illustrations are the successive accretions of Quesnellia, Stikinia, and Wrangellia terranes to the North American Cordillera (Ricketts, 2008), the intra-oceanic subduction of the Pontus Ocean (van der Meer et al., 2012), and the progressive closure of the MongolOkhotsk Ocean suturing the Siberian and Asian cratons (Cogné et al., 2005) (Figure1).

These geodynamic events had major influences on the paleoclimatic and geochemical changes recorded during the Jurassic (Jenkyns et al., 2002; Dera et al., 2011). For example, new circum-global currents passing through the Hispanic Corridor and changes in Tethyan circulation patterns are suspected to have affected heat and moisture transport during the Early Pliensbachian and Middle Oxfordian, leading to changes in atmospheric temperature, continental runoff, and marine sedimentation in the Euro-Boreal domains (Louis-Schmid et al., 2007; Rais et al., 2007; Dera et al., 2009b). Over the long term, the paleoclimatic feedback is also well documented by sedimentological and modelling evidence showing important shifts from warm arid conditions during the Triassic to more humid climates in the Cretaceous (Frakes et al., 1992; Donnadieu et al., 2006). Moreover, the rhythm of volcanic pulses, orogenic phases, and changes in continental drainage imposed by plate movements are of prime importance for modulating atmospheric $p \mathrm{CO}_{2}$ levels through degassing and silicate weathering (Berner and Kothavala, 2001). Finally, paleogeographic reorganisations are very likely to have influenced the distribution of paleoclimatic belts and albedo processes. 
Few studies, however, have attempted to fully assess the long-term interactions between paleoclimate, continental drainage, oceanic circulation, and volcanism during the Jurassic dislocation of Pangea. In this context, analyses of the neodymium (Nd) isotope composition of sediments and seawater may be especially useful (Lacan and Jeandel, 2005). Application of this proxy to geological times, denoted $\varepsilon_{\mathrm{Nd}(\mathrm{t})}$, is based on the principle that rocks weathered on continents as well as their resulting sediments have different $\mathrm{Nd}$ isotope compositions according to their origin (mantle vs. crust) and age (DePaolo, 1988; Frank, 2002). Through fluvial discharges and rapid boundary exchange processes at the watersediment interface (Goldstein and Jacobsen, 1987; Pearce et al., 2013; Wilson et al., 2013), seawater acquires a $\varepsilon_{\mathrm{Nd}(\mathrm{t})}$ signal reflecting all potential sources in the drainage area (Jeandel et al., 2007). As the $\mathrm{Nd}$ residence time is relatively short compared with the global oceanic mixing rate, the geochemical signature of seawater is deemed regionally conservative (Goldstein and Hemming, 2003; Tachikawa et al., 2003), and very suitable for tracking temporal changes in water mass circulation or continental weathering inputs over geological and recent time (e.g. Shaw and Wasserburg, 1985; Patchett et al., 1999; Thomas et al., 2003; Scher and Martin, 2004; Pucéat et al., 2005; McLeod et al., 2008; Dopieralska et al., 2012; Martin et al., 2012; Woodard et al., 2013; Zheng et al., 2013). To assess the $\varepsilon_{\mathrm{Nd}(\mathrm{t})}$ signal of past seawater, various archives have been used, including authigenic minerals such as glauconite, phosphorite, marine carbonate, manganese lenses or Fe-Mn oxyhydroxide phases dispersed in sediments, as well as fossil hard parts like fish teeth and debris, Fe-Mn coatings on foraminifers, microbialites, and belemnite rostra (e.g. Shaw and Wasserburg, 1985; Keto and Jacobsen, 1988; Olivier and Boyet, 2006; Soudry et al., 2006; Martin et al., 2010; Charbonnier et al., 2012). Among these, fish teeth are especially suitable because they concentrate dissolved $\mathrm{Nd}$ in a short time after deposition and remain very resistant to diagenetic alteration (Martin and Scher, 2004).

In contrast to Cenozoic or Cretaceous studies, research focusing on the $\mathrm{Nd}$ isotope composition of Jurassic seawater is still sparse and limited to a few epicontinental basins. Yet early results have proved to be highly promising. For example, $\varepsilon_{\mathrm{Nd}(\mathrm{t})}$ data indicate that the Tethyan oceanic water was radiogenic and highly influenced by Panthalassan currents during the Early and Middle Jurassic, subsequently becoming less radiogenic owing to stronger continental fluxes driven by worldwide rises of weathering rates (Keto and Jacobsen, 1988; Stille et al., 1989; Stille and Fischer, 1990; Stille et al., 1996). Successive Jurassic data from the Paris Basin (France) also indicate that the epicontinental seas of Euro-Boreal basins were influenced primarily by northern unradiogenic crustal-derived inputs from Laurasian cratons 
but sporadically experienced short-term (i.e., to the ammonite chron level) modifications in circulation patterns characterized by stronger south-easterly radiogenic influxes from the Tethyan Ocean (Dera et al., 2009b).

In this study, we present new Jurassic seawater $\varepsilon_{\mathrm{Nd}(\mathrm{t})}$ values from three separate NW Tethyan and Panthalassan domains in order to investigate the spatiotemporal variability of geochemical signals at the ammonite chron resolution ( 0.1 to $2 \mathrm{Myr})$. By compiling all published $\varepsilon_{\mathrm{Nd}(\mathrm{t})}$ values measured on worldwide detrital sediments, we also specify the sources of $\mathrm{Nd}$ and the global drainage pathways that influenced seawater signatures throughout the Jurassic Period. By combining these two approaches, we aim to better document potential changes in marine surface circulation and continental drainage resulting from the Pangean dislocation and, ultimately, test their implications to the regional record of changes in Jurassic seawater temperatures.

\section{Material and Method}

\subsection{Geological setting}

Fifty-three samples of phosphatized fossils and sediments deemed to record the $\varepsilon_{\mathrm{Nd}(\mathrm{t})}$ signatures of Jurassic seawater and erosional inputs were collected from museum collections or personal investigations (Table 1). In almost all cases, each sample was dated at the resolution of an ammonite chron. Our sampling covers a large area including western European, western Russian, and North American basins, all of which, during the Jurassic, included marine paleoenvironments marked by large differences in oceanic and erosional influences.

\subsubsection{Euro-Boreal domain}

Twenty-five samples were obtained from Swabian and North-West German basins (Germany), Wessex Basin (England), Sud-Est and Paris basins (France) and Bornholm Island (Denmark) (Figure 2A). The paleogeography of this area, located between 20 and $35^{\circ} \mathrm{N}$, was characterized by restricted marine basins of 100 to $200 \mathrm{~m}$ depth (Thierry et al., 2000), subjected intermittently to southern influxes from the Tethyan Ocean or to Arctic influences by currents crossing the narrow Viking Corridor (Bjerrum et al., 2001; Dera and Donnadieu, 2012) (Figure 2C). The Precambrian Laurasian cratons and the low reliefs inherited from Caledonian and Hercynian orogenies fronted the tropical seas and acted as the principal 
suppliers of sediments. Volcanism was scarce and restricted to sporadic explosive or effusive events located in the northern basins (i.e., Forties, Zuidwal, Skåne, Egensund) (van Bergen and Sissingh, 2007) (Figure 2C).

\subsubsection{Russian Platform}

Twenty-two samples were collected from sections located in the Kostroma, Kursk, Moscow, Saratov, and Ul'yanovsk regions. During the Middle and Late Jurassic, these areas formed a large transcontinental seaway of 100 to $200 \mathrm{~m}$ depth ranging from 40 to $70^{\circ} \mathrm{N}$, which connected the Arctic domain to the Tethyan Ocean through the Mezen-Pechora Strait to the north and the Caspian Strait to the south (Baraboshkin, 2004) (Figure 2C). This domain was delimited by Precambrian landmasses both westward and southward (i.e., FennoScandian and Ukrainian shields), Uralian highlands to the east, and probably influenced by southerly Caucasian volcanic inputs related to the Cimmerian arc bordering the Tethyan subduction area (Kazmin et al., 1986). Regional tectonic events and sea-level changes played a considerable role in the opening and the restrictions of the Russian seaway, as well as the direction of marine currents. For example, the prevalence of shallow lagoonal facies in the Caspian region and the disappearance of ammonites with sub-Mediterranean affinities indicate that the Russian Platform was progressively disconnected from the Tethyan Ocean but further connected to the Arctic domain during the latest Jurassic (Middle Volgian) (Rogov et al., 2008; Rogov, 2012).

\subsubsection{Panthalassan domain}

North American samples come from outcrops located in Nevada, Haida Gwaii (British Columbia), and Alaska, which represented contrasting paleoenvironments of the eastern Panthalassa (Figure 2B). At this time, numerous magmatic terranes (e.g. Wrangellia, Stikinia, Quesnellia, Klamath-Sierra, Guerrero terranes) drifted eastward and accreted to the American Craton during the Triassic to the Cretaceous (Monger et al., 1982) (Figure 2D). These successive subduction and collision events formed a proto-Cordillera separating intracratonic basins to the east (i.e., the Western Interior Seaway) from the open oceanic domain to the west (Burgess, 2008). Sedimentological data indicate that the incipient reliefs were high enough to prevent massive inputs from the hinterland (i.e., mainly desert deposits) reaching the miogeocline from the south (Dickinson and Gehrels, 2010). On the western side, the basins were regularly influenced by frequent volcanic arc input (Petersen et al., 2004). According to recent reconstructions, samples from Nevada relate to shelfal (ca. $100 \mathrm{~m}$ depth) 
paleoenvironments of the western American margin, whereas those from Haida Gwaii and Alaska reflect open marine domains corresponding to the Wrangellia and Peninsular terranes.

\subsection{Analytical approach}

Thirty-seven fish teeth were selected from well-dated sedimentary levels in the basins mentioned above. Even though diagenetic alteration may occasionally occur in them, due to differences in porosity and microstructure (Kocsis et al., 2010), fish scales, fish bones, ichthyosaur bones, phosphatized ooids and nodules were selected when fish teeth were not available. In this case, we also sampled seven sedimentary matrices (i.e., marl, siltstone or clay) surrounding selected fossils and clasts for comparing the $\varepsilon_{\mathrm{Nd}(\mathrm{t})}$ signals of seawater and detrital inputs, and to check for any potential diagenetic contamination.

Samples were analysed over a three-year period at two laboratories in France (GET at the University of Toulouse and Ifremer in Plouzané). In both places, samples were cleaned in an ultrasonic bath and finely crushed with an agate mortar. Based on material availability, between 6 and $200 \mathrm{mg}$ of phosphate powder and $\sim 100 \mathrm{mg}$ of ground bulk sediments were used for $\mathrm{Nd}$ isotopic measurements. In Toulouse, all teeth samples were dissolved with $4 \mathrm{~mL}$ of twice sub-boiled $\mathrm{HCl} 10 \mathrm{~N}\left(120^{\circ} \mathrm{C}\right.$ on hotplate for two days). Any undissolved material was further treated with a mixture of $1 \mathrm{~mL} \mathrm{HNO}_{3} 15 \mathrm{~N}$ and $0.5 \mathrm{~mL}$ concentrated $\mathrm{H}_{2} \mathrm{O}_{2}$ heated on hotplate at $70^{\circ} \mathrm{C}$. Bulk sediments were digested using a MARS 5 microwave reaction System (CEM) with a mixture of $3 \mathrm{~mL} \mathrm{HF,} 9 \mathrm{~mL} \mathrm{HNO} 315 \mathrm{~N}$, and $2 \mathrm{~mL} \mathrm{HCl} 10 \mathrm{~N}$. The mixed solutions were heated at $180^{\circ} \mathrm{C}$ for 10 min with a ramp time of $15 \mathrm{~min}$ according to the protocol developed at the GET laboratory. Blanks and one certified reference material (OU-8, calcareous sandstone) were measured repeatedly during the course of each session to assess the validity of the procedure. Prior to the Nd purification, aliquots of each sample were spiked with a mixed indium/rhenium solution used as internal standards for the determination of trace element abundances by ICP-MS. Nd was separated from the other elements by ion exchange chromatography using Eichrom's Ln resin (50-100 mesh).

The ${ }^{143} \mathrm{Nd} /{ }^{144} \mathrm{Nd}$ ratios were analyzed on a TIMS Finnegan Mat 251 at the GET laboratory and corrected for mass discrimination by using a ${ }^{143} \mathrm{Nd} /{ }^{144} \mathrm{Nd}$ of 0.7219 with an exponential law. During the period of measurement, repeated analyses of the La Jolla standard gave $0.511845 \pm 0.000005(2 \sigma, n=5)$. Nd levels in procedural blanks were less than $250 \mathrm{pg}$, which is negligible relative to the $\mathrm{Nd}$ signals measured in this study. All corrected ${ }^{143} \mathrm{Nd} /{ }^{144} \mathrm{Nd}$ values are reported in Table 1 . The $\mathrm{Nd}$ isotopic ratios are expressed with the 
epsilon notation $\varepsilon_{\mathrm{Nd}(\mathrm{t})}$, and include corrections related to the radioactive decay of ${ }^{147} \mathrm{Sm}$ to

${ }^{143} \mathrm{Nd}$ through time (based on measured $\mathrm{Nd}$ and Sm concentrations and the law ${ }^{147} \mathrm{Sm} /{ }^{144} \mathrm{Nd}=$ $\mathrm{Sm} / \mathrm{Nd} \times 0.6049)$, the mean numerical ages $(t)$ of ammonite chrons (Gradstein et al., 2012), and the ${ }^{147} \mathrm{Sm}$ radioactive decay constant $\lambda\left(6.54 \times 10^{-12}\right)$. Finally, the ${ }^{143} \mathrm{Nd} /{ }^{144} \mathrm{Nd}_{\mathrm{CHUR}}$ ratio was corrected for post-sedimentation decay of ${ }^{147} \mathrm{Sm}$ using a present-day value of 0.512638 and a ${ }^{147} \mathrm{Sm} /{ }^{144} \mathrm{Nd}$ ratio of 0.1966 (Jacobsen and Wasserburg, 1980).

Note that seven samples (marked with asterisks in Table1) were analyzed at Ifremer by following the protocol described in Charbonnier et al. (2012). In this case, the main methodological difference with the procedure described above concerns the method used for digesting sediments, which was performed by alkaline fusion (Bayon et al., 2009). In addition, as $\mathrm{Nd}$ and $\mathrm{Sm}$ abundances were not measured directly, we calculated the $\varepsilon_{\mathrm{Nd}(\mathrm{t})}$ of these seven samples by assuming an average literature ${ }^{147} \mathrm{Sm} /{ }^{144} \mathrm{Nd}$ value of $0.115 \pm 0.02$, which gives a maximal error of \pm 0.4 units on the $\varepsilon_{\mathrm{Nd}(\mathrm{t})}$ values. The Fe-Mn oxyhydroxide phases of one sediment sample (B4-Fe) were also extracted by sequential leaching (Bayon et al., 2002), in order to provide information on the $\mathrm{Nd}$ isotope composition of corresponding seawater signature (Négrel et al., 2006; Martin et al., 2010).

\subsection{Data compilation}

In order to compare our results to worldwide data, we created an exhaustive database of Jurassic $\varepsilon_{\mathrm{Nd}(\mathrm{t})}$ values (available upon request), compiling results from forty-four publications. This includes 86 values measured on materials inferred to record the seawater signal, such as fish teeth and bones, glauconite, belemnites, early diagenetic Fe-Mn coatings, Mn lenses, pure marine carbonates with Ce anomaly (Stille et al., 1996; Négrel et al., 2006; Olivier and Boyet, 2006; Dera et al., 2009b; Malfilatre et al., 2012), as well as 425 values of sediments and metasediments deemed to preserve the initial rock signal (Mahlen et al., 2005). In order to be homogeneous in the data treatment, all published $\varepsilon_{\mathrm{Nd}(\mathrm{t})}$ values were biostratigraphically recalibrated (if possible) and recalculated by assuming updated numerical ages of Gradstein et al. (2012), ${ }^{147} \mathrm{Sm} /{ }^{144} \mathrm{Nd}=\mathrm{Sm} / \mathrm{Nd} \times 0.6049$, or average values of $0.115 \pm$ 0.02 if $\mathrm{Sm}$ and $\mathrm{Nd}$ concentrations were not available. Consequently, it is possible that our recalculated $\varepsilon_{\mathrm{Nd}(\mathrm{t})}$ values differ slightly from their original publications.

\section{Results}


In order to compare the geochemical variations through time, we plotted our new $\varepsilon_{\mathrm{Nd}(\mathrm{t})}$ values with previously published Jurassic data by separating the Euro-Boreal epicontinental domains, the Russian Platform, and the peri-oceanic areas of Tethys and Panthalassa (Figure 3). We assume that the new and published values measured on different biogenic or authigenic materials recording seawater signals are comparable because the dispersal observed at the same stratigraphic level within the same locality is generally low (e.g. $\leq 1 \varepsilon$ unit from the Callovian to the Tithonian in the Euro-Boreal domain).

\subsection{Reliability of $\varepsilon_{N d(t)}$ signals}

First, it is noteworthy that, for all biogenic or authigenic materials combined, the longterm trends displayed by $\varepsilon_{\mathrm{Nd}(\mathrm{t})}$ values of Euro-Boreal, peri-Tethyan, and Russian basins are very similar through time. This attests that the diagenetic overprints were of minor influence and that the data are sufficiently robust to depict temporal changes in regional seawater composition. Whatever the studied basins of the NW Tethys, the new values measured on phosphatized materials or Fe-Mn coatings are in the range of previously published data and systematically higher by 1.5 to $3 \varepsilon$-units compared with the sedimentary values (e.g. Toarcian and Kimmeridgian of the peri-Tethyan and Russian platforms, respectively). This offset corresponds to that observed by Charbonnier et al. (2012) or Martin et al. (2012) for Cretaceous samples from the Western Interior Seaway and Demerara Rise. Thus, we suggest that these $\varepsilon_{\mathrm{Nd}(\mathrm{t})}$ values may be mainly interpreted as unaltered seawater signatures.

In contrast, ichthyosaur bones and fish scales from North American terranes yield abnormal positive values (i.e., $\varepsilon_{\mathrm{Nd}(\mathrm{t})}$ from 3.2 to 8.7 ), much higher than modern ocean values (Lacan et al., 2012). Owing to the porous nature of bones (Kocsis et al., 2010), a large diagenetic uptake from volcanic sources is therefore suggested, consistent with the strong volcanic-arc components of these terranes. Such values were consequently ruled out for seawater interpretation. Only the value measured on an Early Pliensbachian phosphate nodule from Nevada (-3.4) seems reliable for Panthalassan seawater signal, as it is in the range of previously published data (Chyi et al., 1984), is comparable to modern Pacific values (Lacan et al., 2012), and is distinct from its sedimentary matrix.

\subsection{Seawater $\varepsilon_{N d(t)}$ patterns}


Overall, our results illustrate a strong heterogeneity of seawater $\varepsilon_{\mathrm{Nd}(\mathrm{t})}$ signatures across the Jurassic oceans (Figure 3). Even if values are very sparse and call for further investigation in the future, Panthalassan waters are typically more radiogenic than the others (-4.4 to $-3.4 \varepsilon-$ units). In the NW Tethyan domains (including Euro-Boreal, peri-Tethyan, and western Russian areas), values are generally more negative, but locally exhibit short-term rises toward values exceeding $-7 \varepsilon$-units, a value chosen here arbitrarily as the lower estimate of radiogenic signals from equatorial Tethyan oceanic currents (i.e., Arabian Platform value). It is also noteworthy that trends recorded in the Euro-Boreal and peri-Tethyan domains are very similar in terms of timing and amplitudes, although $\varepsilon_{\mathrm{Nd}(\mathrm{t})}$ signatures of open marine waters appear slightly more radiogenic ( $+1 \varepsilon$-unit on average).

Six isotopic features displaying amplitudes of at least $2 \varepsilon$-units are successively recorded in the Euro-Boreal and peri-Tethyan epicontinental seawaters: 1) a steady unradiogenic signal from the Sinemurian to the Pliensbachian interrupted by a positive excursion of $+2 \varepsilon$-units at the Early - Late Pliensbachian transition; 2) a decreasing signal followed by steady low values (between -10 and -8 ) during the Toarcian, except in the North West German Basin where a more radiogenic value (-5.8) is recorded; 3) a long-term rise of $+3 \varepsilon$-units during the Aalenian with relatively radiogenic values up to the Bathonian; 4) a drop of -2 $\varepsilon$-units in the Callovian - Early Oxfordian interval with slight fluctuations at the boundary; 5) a sharp rise of +3 to $+4 \varepsilon$-units in the Middle Oxfordian; 6) a noisy decrease of values during the Late Oxfordian followed by steady unradiogenic values (-10 to -8$)$ from the Kimmeridgian to the Tithonian. In the Russian Platform, the long-term trends are similar but the seawater $\varepsilon_{\mathrm{Nd}(\mathrm{t})}$ appears comparatively much more radiogenic from the Middle Jurassic to the Early Oxfordian (up to -4.1 during the Bathonian), then follows a long-term decrease during the Late Jurassic. We also note that values fluctuate strongly and rapidly during the Callovian - Early Oxfordian interval (i.e., during the fourth event).

\section{Discussion}

\subsection{Continental sources of Nd during the Jurassic}

Before discussing the origin of Jurassic seawater $\varepsilon_{\mathrm{Nd}(\mathrm{t})}$ patterns, it is of prime importance to understand: 1) what were the continental sources of $\mathrm{Nd}$ to oceans at that time; and 2) how drainage pathways may have evolved during this period. For this purpose, we compiled all available $\varepsilon_{\mathrm{Nd}(\mathrm{t})}$ values of clastic sediments deposited during the Jurassic at a 
global scale. Higher and lower Jurassic values are plotted on a paleogeographic map in order to show the spatial heterogeneity of $\mathrm{Nd}$ sources in different domains (Figure 4). When possible, the temporal evolution of sedimentary $\varepsilon_{\mathrm{Nd}(\mathrm{t})}$ values is also reported for each basin on Figure 5 to depict potential changes in Nd sources through the Pangean dislocation.

\subsubsection{Panthalassan areas}

The spatial distribution of sedimentary $\varepsilon_{\mathrm{Nd}(\mathrm{t})}$ values shows a worldwide heterogeneity in neodymium sources (Figure 4), which seems quite constant during the Jurassic (Figure 5). The most noticeable feature is the highly radiogenic signature of circum-Pangean sediments (up to +10 ), related to the erosion and weathering of juvenile volcanic arcs or oceanic island basalts, whose mean modern $\varepsilon_{\mathrm{Nd}}$ signals lie between -1 and $10 \varepsilon$-units and -6 to $9 \varepsilon$-units, respectively (Shaw and Wasserburg, 1984). This pattern attests to the effectiveness of a Jurassic Ring of Fire as the main supplier of radiogenic $\mathrm{Nd}$ isotopes to Panthalassa, as observed for the modern Pacific Ocean (Jeandel et al., 2007). It is suggested that the incipient growth of the Pacific plate drove increases in subduction rates attended by volcanic pulses and arc collisions, which were especially important during the Kimmeridgian (Bartolini and Larson, 2001; Kalnins and Watts, 2009). This circum-Panthalassan activity is well illustrated along the western coasts of USA, Canada, and Mexico (DeBari et al., 1999; Clift et al., 2005; Barboza-Gudiño et al., 2008), Andes and Patagonia (Féraud et al., 1999; Boekhout et al., 2012), New Zealand (Briggs et al., 2004), Northeast and Far East Russia (Sey et al., 1992), and Japan (Isozaki et al., 2010), where thick ash or volcaniclastic sequences, as well as magmatic effusions are recorded on terranes and continental margins.

In North America, the $\varepsilon_{\mathrm{Nd}(\mathrm{t})}$ signatures of sediments were highly radiogenic but marked by obvious heterogeneities from insular volcanic terranes to epicontinental basins (Patchett and Gehrels, 1998; Petersen et al., 2004). According to Patchett et al. (1999) and Dickinson and Gehrels (2010), the continental inputs consisted mainly of unradiogenic sands and muds derived from mid-Paleozoic strata and transported by a river network coming from the Appalachian highlands and crossing the North American craton. Some of the sediments reached the oceanic margin by northern routes, whereas the southern margin was blocked by a proto-cordillera and sediments were consequently deposited in intracratonic basins. This scenario explains why eastern sediments from Alberta and the Western Interior Seaway show low $\varepsilon_{\mathrm{Nd}(\mathrm{t})}$ values of -10 to $-6 \varepsilon$-units (Patchett and Gehrels, 1998; Tütken et al., 2011), compared with those deposited on the western Nevada margin ( $-4 \varepsilon$-units) preserved from voluminous continental supplies. 
Comparatively, the isotopic signature of sediments deposited on southern Gondwanan terranes and margins (i.e., Chile, Antarctica, New Zealand, New Caledonia) appears slightly less radiogenic (-6 to $6 \varepsilon$-units) (Frost and Coombs, 1989; Adams et al., 2005). This reflects a more efficient mixing between juvenile volcanic sources and mature continental inputs. But more surprising is the very unradiogenic signature (-20 to $0 \varepsilon$-units) of sediments from eastern Asian margins surrounding the Amurian reliefs, although arc volcanism also prevailed here (Lan et al., 2002; Kagami et al., 2006; Yang et al., 2010; Zhang et al., 2011; Fu et al., 2012; Xie et al., 2012). Only deposits of the northern Mongol-Okhotsk margin display radiogenic signals compatible with juvenile inputs (Sjostrom et al., 2001; Tütken et al., 2011). As demonstrated by Wang et al. (2013), the Amurian block suffered considerable deformation related to the subductions of the Tethys, Pontus, and Mongol-Okhotsk oceans (Figure 1). Compatibly with detrital zircon U-Pb dating of Jurassic sediments from this area (Yang et al., 2010), the exhumation and erosion of former (i.e., mainly Paleoproterozoic, Ordovician and Carboniferous) crustal and sedimentary rocks likely promoted huge unradiogenic Nd inputs on Asian epicontinental margins, massively diluting any proximal volcanic source.

\subsubsection{Arctic and Tethyan areas}

Compared with Panthalassan domains, the sedimentary signature of NW Tethyan, West Russian, and Arctic epicontinental basins is much less radiogenic. Moreover a noticeable isotopic gradient prevails from high to low latitudes, with very low $\varepsilon_{\mathrm{Nd}(\mathrm{t})}$ values in the Sverdrup and North Sea basins (-22 to -8 $\varepsilon$-units) (Mearns, 1989; Ehrenberg et al., 1998; Patchett et al., 2004), and higher values in the vicinity of Tethyan open marine domains (up to $-4 \varepsilon$-units) (Mahlen et al., 2005).

In a context of pronounced basinal restrictions, the very low $\varepsilon_{\mathrm{Nd}(\mathrm{t})}$ values measured in the Arctic-Boreal sediments may be explained firstly by the influence of unradiogenic sands, silts, and clays derived from Archean to Paleozoic crustal rocks from Canadian, Greenland, or Fenno-Scandian shields. Modern sediments from these regions (e.g. Labrador Sea) still yield typically low $\mathrm{Nd}$ isotope ratios (Jeandel et al., 2007). In the light of mineralogical and geochemical evidence, it is nevertheless noticeable that the sedimentary sources evolved during the Pangean dislocation (Mearns et al., 1989). This is well documented during the marine extension of the Viking Corridor at the Sinemurian-Pliensbachian transition (Figure 5A), when very unradiogenic Archean inputs from western reliefs were progressively replaced by more radiogenic inputs derived from Proterozoic rocks or recycled Paleozoic strata from eastern and southern highs (Morton et al., 2009). More sporadically, positive 
$\varepsilon \operatorname{Nd}(\mathrm{t})$ peaks recorded in Sinemurian and Bajocian strata of the North Sea basins would suggest brief regional volcanic pulses in Greenland and in the Forties regions (Mearns, 1989).

In the Euro-Boreal, Sub-Boreal, and West Russian domains (Figure 5A), the direct influence of boreal Precambrian cratons was buffered by younger $\mathrm{Nd}$ sources related to Caledonian, Hercynian, and Uralian crustal massifs, as well as recycled Paleozoic strata contributing to enhance the $\varepsilon_{\mathrm{Nd}(\mathrm{t})}$ of sediments between -14 and -9 $\varepsilon$-units (Davies et al., 1985; Michard et al., 1985; Liew and Hofmann, 1988). Although the number of data points is still insufficient for a definitive interpretation, the sedimentary $\varepsilon_{\mathrm{Nd}(\mathrm{t})}$ values of Sub-Boreal (i.e., Yorkshire, northern Germany) and Euro-Boreal basins (i.e., Paris, Wessex, and Swabian basins) became progressively distinct during the Middle and Late Jurassic, suggesting that the drainage pathways likely evolved along paleogeographic modifications.

In the peri-oceanic and oceanic sub-basins of the NW Tethys, higher sediment $\varepsilon_{\mathrm{Nd}(\mathrm{t})}$ values suggest a mixing between recycled crustal rocks and juvenile volcanic materials (Mahlen et al., 2005), tentatively related to the extensions of the Piemont-Ligurian, Maliac, Vardar, and Pindos oceans, which were especially dynamic during the Middle and Late Jurassic (Channell and Kozur, 1997) (Figure2C). Eastward, Cimmerian volcanic arcs prevailed along the northern Tethyan subduction zone (i.e., Pontides, Caucasus, Crimea, Zagros) (Kazmin et al., 1986; Meijers et al., 2010), which could also have major influences on the geochemical composition of erosional inputs. To our knowledge, no sedimentary values from these regions are currently available but $\varepsilon_{\mathrm{Nd}(\mathrm{t})}$ analyses performed on coeval magmatic rocks reveal characteristic radiogenic values (i.e., 0 to $4 \varepsilon$-units in the Pontides) (Şen, 2007; Dokuz et al., 2010). While awaiting future confirmation, this would suggest that sediments from the northern Tethyan active margin were partly radiogenic and mixed with old recycled inputs.

Finally, no Jurassic data are currently available for the southern margin of Tethys but we presume that sediments had low Nd signatures related to crustal inputs from Precambrian basements of African and Indian cratons. In agreement, recent $\mathrm{U}-\mathrm{Pb}$ dating and $\varepsilon_{\mathrm{Nd}(\mathrm{t})}$ analyses of poorly-dated Mesozoic sands from Libya and Ghana, respectively, reveal that recycled Precambrian rocks were the foremost source of sediments deposited in intracratonic basins and along passive margins of Gondwana (Asiedu et al., 2005; Meinhold et al., 2011).

\subsection{The $\varepsilon_{\mathrm{Nd}(\mathrm{t})}$ signatures of Tethyan and Panthalassan oceans}


The global distribution of sedimentary $\varepsilon_{\mathrm{Nd}(\mathrm{t})}$ values demonstrates that the continental sources of neodymium were very heterogeneous in the Jurassic world and driven by complex interactions between volcanic regimes, reliefs, and river drainage pathways. Through direct fluvial $\mathrm{Nd}$ supplies from continents, as well as boundary exchanges with sediments on epicontinental margins (Jeandel et al., 2007), this worldwide heterogeneity contributed to differentiate the isotopic signatures of surface seawaters of different regions (Figure 6).

Pooled with previously published Jurassic data measured on manganese lenses from the Franciscan Complex (Chyi et al., 1984), the new results from the Nevada margin show that the $\varepsilon_{\mathrm{Nd}(\mathrm{t})}$ signature of neritic American Panthalassan waters was quite radiogenic (i.e, around $-4 \varepsilon$-units), and very similar to those of Cretaceous, Cenozoic, and modern Pacific waters (Thomas et al., 2003; Lacan et al., 2012; Martin et al., 2012; Moiroud et al., 2013). Even if the values are very sparse and necessitate further investigation, it is worth noting that the $\varepsilon_{\mathrm{Nd}(\mathrm{t})}$ values from these two areas are very concordant in spite of their distinct paleoenvironments and water depths (i.e., deep accretionary complex vs. epicontinental shelves). Through a dominant influence of volcanic influxes from the active Ring of Fire, this suggests that the isotopic budget of Nd inputs did not change significantly in Panthalassa over $200 \mathrm{Myr}$ (Stille et al., 1996), and could have been quite homogeneous through the water column bordering the western American craton. As in modern oceans, it may also be supposed that surface currents actively diffused $\mathrm{Nd}$ isotopes from shelfal and insular paleoenvironments toward open marine domains. Indeed, recent numerical models based on Jurassic paleogeography suggest that strong westward Panthalassan currents prevailed toward the equator and that important gyres transported warm subtropical waters toward the poles by following clockwise and anticlockwise movements in the two hemispheres (Dera and Donnadieu, 2012) (Figure 7). Unfortunately, no Nd isotope data from open oceanic domains currently confirm the homogeneity of seawater $\varepsilon_{\mathrm{Nd}(\mathrm{t})}$ values for the whole of Panthalassa.

In Tethys, the seawater $\varepsilon_{\mathrm{Nd}(\mathrm{t})}$ signal from epicontinental margins was less radiogenic (i.e., mean value around $-8 \varepsilon$-units) and marked by a strong disparity of values varying between of -12 and $-4 \varepsilon$-units (Figure 6). Comparatively, this range corresponds to those observed in current surface waters from the Mediterranean Sea and Indian Ocean (Lacan et al., 2012). Similarities in basinal restriction, sources, and geodynamic regimes may therefore be invoked. Moreover, our intraregional comparison highlights an isotopic gradient in NW Tethys, with high $\varepsilon_{\mathrm{Nd}(\mathrm{t})}$ values of -6.3 $\varepsilon$-units for equatorial waters of the Arabian Platform, intermediate values of -7.4 $\varepsilon$-units in the peri-oceanic and Russian areas, and a minimum of $8.6 \varepsilon$-units in the Euro-Boreal basins. Once again, this pattern seems directly related to the 
combined influences of regional Nd sources and oceanic circulation (Figure 7). In the absence of a proximal radiogenic source, the high seawater $\varepsilon_{\mathrm{Nd}(\mathrm{t})}$ value measured by Grandjean et al. (1987) in fish teeth from the Arabian seas supports the hypothesis of Stille et al. (1996) invoking the direct influence of radiogenic water masses from the equatorial Panthalassan Ocean. These surface water masses clearly dominated any local input from recycled Precambrian crust. This scenario is consistent with numerical simulations showing rapid subsurface currents flowing westward in equatorial Tethys, splitting around the Arabian Platform, and subsequently drifting along the Gondwanan shelves (Dera and Donnadieu, 2012). Through a progressive influence of old continental landmass inputs northward, these water masses gradually lost their radiogenic composition, as observed for modern currents drifting close to contrasted emergent sources (Horikawa et al., 2011). This is very obvious in NW Tethys, where seawater $\varepsilon_{\mathrm{Nd}(\mathrm{t})}$ signals decreased on average of $-1.2 \varepsilon$-units between the peri-Tethyan domains bordering the deep oceanic basin and the restricted Euro-Boreal seas.

However, it cannot be excluded that independent continental radiogenic sources regionally ensured high seawater $\varepsilon_{\mathrm{Nd}(\mathrm{t})}$ signals on the NW Tethyan shelves. For example, it is likely that radiogenic $\mathrm{Nd}$ inputs from proximal volcanic sources located in the Cimmerian arcs sporadically contributed to the comparatively higher $\varepsilon_{\mathrm{Nd}(\mathrm{t})}$ values displayed by Russian seawaters during the Middle Jurassic (Kazmin et al., 1986) (Figure 6). Even if supporting data are few, it is also possible that recurrent volcanic events contributed to increases in seawater $\varepsilon_{\mathrm{Nd}(\mathrm{t})}$ in the hemipelagic domains of NW Tethys (i.e., Vardar, Pindos, Meliac oceans). In southernmost domains, volcanic arcs linked to intra-oceanic subduction of the Mesotethyan plate have also been reported (Hall, 2012). Nevertheless their influence on the whole Tethyan signature was certainly minor because eastward surface currents drifting along southern Gondwanan margins exported radiogenic water masses in the southern Panthalassan Ocean (Dera and Donnadieu, 2012) (Figure 7).

In a pioneering study of the general patterns of $\mathrm{Nd}$ isotope composition of past oceans, Stille et al. (1996) demonstrated that the $\varepsilon_{\mathrm{Nd}(\mathrm{t})}$ signature of Tethyan seawaters was not differentiated from the Panthalassan one prior to the Late Jurassic, when stronger continental weathering rates progressively decreased the values. In the light of our new isotopic data, this scenario may be partly reappraised as temporal trends recorded in the NW Tethyan basins appear much more complex (Figure 8). Indeed, we note that in the Early Jurassic, the two oceanic signals were already distinct, even if Panthalassan water masses regionally influenced the Tethyan seawater geochemistry in equatorial areas. Moreover, numerous short-term 
isotopic variations (represented here by numbers 1 to 6) are recorded in NW Tethyan waters and likely call for independent interpretations.

\subsection{Origin of seawater $\varepsilon_{\mathrm{Nd}(\mathrm{t})}$ variations in $N W$ Tethys}

\subsubsection{The Pliensbachian positive excursion}

During the Sinemurian-Pliensbachian interval, the seawater $\varepsilon_{\mathrm{Nd}(\mathrm{t})}$ signal recorded by fish teeth from the Paris Basin was around -8.5 $\varepsilon$-units (Dera et al., 2009b), which is the median value of NW Tethyan seawaters for the Jurassic (Figure 8). New $\varepsilon_{\mathrm{Nd}(t)}$ values of fish teeth from the Bornholm Island (Denmark) presented herein confirm the unradiogenic signal and the low disparity between distant European basins in the midst of the Margaritatus Chron. Nevertheless, a major geochemical disturbance occurred at the transition between the Davoei and Margaritatus Chrons, with a noticeable positive excursion. In the light of mollusc $\delta^{18} \mathrm{O}$ data showing a coeval rise in seawater temperatures in the NW Tethys (Rosales et al., 2004; van de Schootbrugge et al., 2005), Dera et al. (2009b) interpreted this event as the incursion of warm radiogenic water masses from equatorial Tethys or eastern Panthalassa. Recently, numerical simulations have discredited the Panthalassan hypothesis by highlighting an important westward oceanic circulation in the Hispanic Corridor (Dera and Donnadieu, 2012). However, they confirm the Tethyan scenario by showing more important incursions of southern currents in the Euro-Boreal seas under high $p \mathrm{CO}_{2}$ levels and warm conditions. The opening of the Hispanic Corridor also likely favoured their acceleration and diffusion toward mid-latitudes. The rise of temperatures recorded by $\delta^{18} \mathrm{O}$ values in NW Tethys could therefore include both a global warming event related to rapid carbon cycle disturbances (Silva et al., 2011), and regional oceanic influences.

\subsubsection{The Toarcian negative shift}

The second major disturbance happened during the Toarcian, a time considered as the warm climatic optimum of the Jurassic (Dera et al., 2011). At this time, seawater $\varepsilon_{\mathrm{Nd}(\mathrm{t})}$ values measured on various biogenic materials decreased by $1.5 \varepsilon$-units in the Euro-Boreal and periTethyan domains (i.e., Paris and Sud-Est basins) and stayed relatively low through the whole interval. Conformingly to recent paleoclimatic models (Dera and Donnadieu 2012), it is possible that this NW Tethyan pattern relates to both a shift of hydrolyzing humid belts toward higher latitudes, and more arid conditions in the peri-Tethyan domains. Combined effects of extended drainage pathways toward boreal sources (i.e., mainly very unradiogenic 
Precambrian cratons of Fenno-Scandia and Greenland) and lower contributions of more radiogenic sources (i.e., derived from Paleozoic orogens and Cimmerian arcs) massively contributed to decrease the NW Tethyan seawater signal. This climatic hypothesis agrees with higher runoff rates and strong fluvial discharges suggested by prominent negative shifts in Euro-Boreal $\delta^{18} \mathrm{O}$ values (McArthur et al., 2000; Bailey et al., 2003), positive shifts in ${ }^{87} \mathrm{Sr} /{ }^{86} \mathrm{Sr}$ and ${ }^{187} \mathrm{Os} /{ }^{188} \mathrm{Os}$ ratios (Jones et al., 1994; Cohen et al., 2002), increasing contents of kaolinite in marine sediments (Dera et al., 2009a), and massive phosphorus, metal, and clastic inputs (Bodin et al., 2011; Lézin et al., 2013) (Figure 8). In addition, southward marine currents diffusing Arctic waters (with supposedly lower $\varepsilon_{\mathrm{Nd}(\mathrm{t})}$ and $\delta^{18} \mathrm{O}$ values) through the Viking Corridor likely contributed to this pattern during the high sea-level of the Toarcian (Bjerrum et al., 2001; Dera and Donnadieu, 2012).

As an aside, it may be noted that a fish tooth recovered from the lower Toarcian of the North West German Basin presents a radiogenic seawater value of $-6 \varepsilon$-units, which is quite counter-intuitive to the idea of massive unradiogenic crustal-derived inputs from Laurasia (Figure 8). As the corresponding clastic fraction displays a similar isotopic increase (Figure 5A), this could correspond to very brief and local radiogenic Nd influxes from the Skåne flood basalts erupted at this time (Bergelin, 2009) (Figure 2).

\subsubsection{The Aalenian - Bathonian positive shift}

In the Middle Jurassic, the seawater Nd isotope signal progressively rose by $3 \varepsilon$-units both in the Euro-Boreal and peri-Tethyan areas, and attained a maximum at the Bajocian Bathonian transition (also recorded in the Lower Bathonian Ishmae Zone of western Russia). This positive evolution is here described for the first time and its origin may be explained by the cumulative effects of paleoclimatic, oceanic, and volcanic factors. First, it is likely that important modifications in the relative contribution of old crustal vs. young volcanic sources acted as a paramount factor. Indeed, this isotopic shift occurred during phases of paroxysmal volcanic activity in the Cimmerian arcs (Kazmin et al., 1986), Forties and Egersund provinces (van Bergen and Sissingh, 2007), as well as Vardar, Maliac, and Pindos oceanic sub-basins (Bonev and Stampfli, 2008). Constant radiogenic influxes from dispersed volcanic sources could therefore explain rises in $\varepsilon_{\mathrm{Nd}(\mathrm{t})}$ values of Euro-Boreal, peri-Tethyan, and Russian seawaters, as well as the parallel shifts observed in the Bajocian clastic fractions of the Viking Corridor and hemipelagic basins of the NW Tethyan Ocean (Mearns, 1989; Mahlen et al., 2005) (Figure 5A). This was likely accentuated by regional drops in the relative contribution of unradiogenic supplies from distal boreal sources, owing to cooler and drier conditions in 
northern Laurasia attested by $\delta^{18} \mathrm{O}$ data (Dera et al., 2011), clay mineralogy (Brigaud et al., 2009), and multiple ice indices in the polar areas (Price, 1999; Rogov and Zakharov, 2010).

The second hypothesis invokes regional changes in oceanic circulation marked by a stronger influence of radiogenic Tethyan waters in northern domains. The origin of this modification remains obscure but it may be noted that this shift occurred in parallel with the North Sea doming event (Underhill and Parkinson 1993), which likely restricted any direct southward diffusion of unradiogenic boreal waters through the Viking Corridor and promoted northward incursions of Tethyan waters. Moreover, this southern influence could be accentuated by a rapid widening and deepening of the Hispanic Corridor attested during the Bajocian (Labails et al., 2010). Indeed, simulations of Hotinski and Toggweiler (2003) show that the creation of a mid-latitude circum-global passage promotes wind-driven upwelling of large volumes of cold deepwater in the tropics. As a consequence, such a scenario would imply that cool seawater temperatures recorded during the Middle Jurassic in the Euro-Boreal basins could reflect regional paleoceanic influences, even if a cooling event also prevailed on a global scale (Rogov and Zakharov, 2010). On the Russian Platform, southern paleogeographical barriers likely prevented these deep current influences but the high seawater $\varepsilon_{\mathrm{Nd}(\mathrm{t})}$ values imply that: 1) in accordance with regional occurrences of Mediterranean Tethyan ammonites in this domain, strong surface Tethyan currents crossing the southern Caspian Strait efficiently diffused dissolved volcanic Nd northward, and 2) the boreal MezenPechora Strait linking the Arctic Ocean to the Russian Platform was not yet fully effective to channel unradiogenic currents southward.

\subsubsection{The Callovian - Early Oxfordian negative shift}

The fourth isotopic event corresponds to a marked drop of about $-2 \varepsilon$-units from the Early Callovian to the Early Oxfordian, which is more pronounced in the Euro-Boreal domains but also recognized on the Russian Platform (although more oscillatory). Importantly, this episode happened during a major transgression considered to have enhanced the marine connections between the Arctic and NW Tethyan seas through a deepening of trans-Laurasian seaways. According to Cariou et al. (1985) and Wierzbowski et al. (2013), this eustatic change led to the southward propagation of cool and deep Arctic water masses reflected by progressive invasions of boreal ammonites and increasing $\delta^{18} \mathrm{O}$ values in the Euro-Boreal and Russian seas (but not in other marine domains, Alberti et al., 2012). Even if the $\varepsilon_{\mathrm{Nd}(\mathrm{t})}$ signature of Arctic seawater is unknown at this time, it may be assumed that it was mainly unradiogenic owing to the prevalence of Precambrian cratons at high latitudes (i.e., 
Greenland, Canadian, Fenno-Scandian, and Siberian shields). Radiogenic influences from weathered Siberian traps likely remained limited to the West Siberian Basin (Dypvik and Zakharov 2012). As a consequence, the southward diffusion of unradiogenic water masses from the polar region seems relevant because it could explain the isotopic gradient observed between northern and southern areas in the NW Tethys (Figure 8). In addition, the influence of stronger continental inputs may be excluded because sedimentological, geochemical, paleontological, and palynological evidence suggests cooler and more arid conditions in the NW Tethys from the mid-Callovian to the Early Oxfordian (Abbink et al., 2001; Cecca et al., 2005; Brigaud et al., 2008). Along the Russian Platform, the decrease in $\mathrm{Nd}$ isotope composition of seawater is less obvious because values strongly oscillate and stay comparatively more radiogenic. The origin of these isotopic fluctuations remains unclear but they likely reflect a circulation pathway characterized by dominant southward boreal currents sporadically alternating with northward Tethyan currents diffusing volcanogenic Nd during times of restriction in the Mezen-Pechora Strait. This complexity in oceanic dynamics through the large Russian Platform coincided with rapid fluctuations in ammonite expansions (Rogov et al., 2008).

\subsubsection{The mid-Oxfordian positive excursion}

A sharp rise in seawater $\varepsilon_{\mathrm{Nd}(\mathrm{t})}$ values is evident in the Euro-Boreal and peri-oceanic areas during the mid-Oxfordian. As this shift does not appear in the Russian Platform, it likely represents a regional signature constrained by paleogeography. According to Négrel et al. (2006) and Sidorczuk et al. (2010), who measured radiogenic values (exceeding -6 $\varepsilon$-units) in authigenic Fe-Mn coatings and pure marine carbonates from the Paris Basin and the Pieniny Klippen Belt, this feature would likely reflect a strengthening of southern Tethyan surface currents intruding the northern domains. Indeed, several lines of evidence support this change, such as brief regional expansions of Tethyan faunas and coral reefs in Euro-Boreal domains (Cecca et al., 2005; Carpentier et al., 2006; Martin-Garin et al., 2012), the transient rises in Euro-Boreal seawater temperatures not evident at a global scale (Wierzbowski, 2004; Brigaud et al., 2008; Alberti et al., 2012), and two brief negative $\delta^{13} \mathrm{C}$ excursions (during the Transversarium Chron) within an overall positive trend interpreted as local clathrate destabilizations by warm bottom waters (Padden et al., 2001). By invoking mechanisms similar to those explained previously, a further widening of the Hispanic Corridor could be responsible for such oceanic events (Louis-Schmid et al., 2007; Rais et al., 2007), which in turn may have contributed to making the paleoclimate regionally warmer and more arid 
(Abbink et al., 2001). But more intriguing is the absence of radiogenic Tethyan incursions in the Russian Platform, whereas Middle Oxfordian invasions of Submediterranean ammonites seem to prove the contrary (Wierzbowski et al., 2013). In accordance with paleobiogeographical evidence, it may be supposed that successive arc accretions on the northern Tethyan margin weakened the Tethyan influence through the Caspian Strait, forcing southern faunas to migrate by western European routes. In parallel, the widening of the Mezen-Pechora Strait likely favoured the diffusion of boreal currents, giving an unradiogenic signature to West Russian seawaters until the end of the Jurassic.

\subsubsection{The Late Oxfordian - Tithonian decrease}

In the Late Oxfordian, the seawater $\mathrm{Nd}$ isotope signal decreased significantly in all studied basins (more abruptly in the Euro-Boreal seas) and remained almost always very unradiogenic until the end of the Jurassic (Figure 8). Similar to the Toarcian event, Négrel et al. (2006) interpreted this trend as an intensification of unradiogenic detrital input from Laurasian landmasses. Through extensions of drainage areas toward boreal unradiogenic sources, this paleoclimatic explanation appears pertinent because GCM simulations and respective shifts in the $\delta^{18} \mathrm{O}$ and $\mathrm{Mg} / \mathrm{Ca}$ values measured on marine molluscs from Scotland and Russian basins reveal the onset of an important warming trend (Nunn et al., 2009; Wierzbowski et al., 2013), which promoted accelerations in the hydrological cycle and shifts in humid belts. Occurrences of strong rainfall, rapid continental weathering rates, and massive nutrient supplies from boreal continental domains are indicated by positive shifts in ${ }^{87} \mathrm{Sr} /{ }^{86} \mathrm{Sr}$ and ${ }^{187} \mathrm{Os} /{ }^{188}$ Os ratios (Jones et al., 1994; Cohen et al., 1999) (Figure 8), higher kaolinite contents in sediments (Hesselbo et al., 2009), increases in clastic inputs, and massive organic matter deposits in the sub-Arctic and Boreal basins (Weissert and Mohr, 1996).

As with the Toarcian, regional changes in oceanic surface circulation cannot be ruled out to explain the low seawater $\varepsilon_{\mathrm{Nd}(\mathrm{t})}$ values recorded in the Euro-Boreal seas. Indeed, locally cool seawater temperatures (i.e., Paris Basin) (Brigaud et al., 2008; Martin-Garin et al., 2010), southward migrations of boreal ammonites, and regional retreats of coral reefs in the Late Oxfordian domains have been interpreted as a vanishing influence of warm Tethyan currents in the Euro-Boreal domains, counterbalanced by a recurrent southward diffusion of unradiogenic boreal waters through the Viking Corridor (Cecca et al., 2005; Rogov et al., 2008; Martin-Garin et al., 2012). This modification could relate to a high sea-level promoting connections between the Arctic and NW Tethyan seas (Figure 8), as well as a canalization of southern Tethyan currents in the Hispanic Corridor as the Gondwanan landmasses drifted 
southward (Figure 1). On the Russian Platform, a progressive regional sea-level fall inferred from widespread lagoonal facies also contributed to this declining influence of Tethyan currents. By the emergence of the Caspian and Brest straits, respectively to the south and south-west of the Russian Platform (Figure 2C), it is possible that this domain became influenced exclusively by unradiogenic boreal waters crossing the Mezen-Pechora Strait, as suggested by the lowest $\varepsilon_{\mathrm{Nd}(\mathrm{t})}$ values and paleobiogeographical data (Rogov, 2012).

\section{Conclusions}

Combined with an extensive compilation of published data, our isotopic $\varepsilon_{\mathrm{Nd}(\mathrm{t})}$ values measured on biogenic and sedimentary materials from Europe, western Russia, and North America, allow a better appraisal of sources, as well as continental and surface oceanic transfers of neodymium during the Jurassic Pangean breakup. Several points are highlighted:

- Owing to strong volcanic inputs from the Ring of Fire, the Jurassic Panthalassan waters were radiogenic and very similar to modern Pacific values ( $-4 \varepsilon$-units). In the Tethyan area, the surface waters were less radiogenic and characterized by a negative isotopic gradient from equatorial neritic domains to Euro-Boreal areas. This disparity is interpreted as a decreasing influence of radiogenic Panthalassan currents flowing westward, counterbalanced northward by stronger contributions of unradiogenic continental sources such as the Precambrian FennoScandian highs and Paleozoic orogens. Comparatively, the Russian Platform was more subject to radiogenic fluxes from juvenile Cimmerian arcs.

- The $\varepsilon_{\mathrm{Nd}(\mathrm{t})}$ values of NW Tethyan waters fluctuated significantly through time, in response to regional changes in paleogeography, continental drainage, oceanic circulation, paleoclimate, and volcanism, which could ultimately be linked to the Pangean dislocation.

- Positive seawater $\varepsilon_{\mathrm{Nd}(\mathrm{t})}$ shifts occurred on the Euro-Boreal and peri-Tethyan platforms in the middle of the Pliensbachian (Event 1) and during the mid-Oxfordian (Event 5). These features could represent incursions of warm surface radiogenic currents from southern Tethys, which could have regionally promoted a warmer climate.

- From the Aalenian to the Bathonian, a protracted positive shift in $\varepsilon_{\mathrm{Nd}(\mathrm{t})}$ is emphasized in parallel with cool seawater temperatures (Event 3). This seems to be linked to increased 
radiogenic supplies from active Cimmerian, Euro-Boreal, and eastern Tethyan volcanoes and/or a stronger influence of Tethyan upwelling events favoured both by the rapid widening of the Hispanic Corridor and a restriction of boreal currents during the North Sea doming.

- Rapid drops in $\varepsilon_{\mathrm{Nd}(\mathrm{t})}$ values are recorded in parallel with the regional seawater cooling and marine transgression observed during the Callovian - Early Oxfordian interval (Event 4). In agreement with geochemical and paleontological evidence, we suggest that influxes of very unradiogenic and cold boreal waters flowing southward through the Viking Corridor and the Mezen-Pechora Strait could be responsible for this negative isotopic trend.

- Two protracted negative $\varepsilon_{\mathrm{Nd}(\mathrm{t})}$ trends prevailed in the boreal basins during the warm conditions of the Toarcian (Event 2) and Late Oxfordian - Tithonian interval (Event 6). These geochemical disturbances seem related to a combination of climatic and oceanic effects, including: 1) northward shifts in humid belts extending the drainage areas toward new boreal sources supplying very unradiogenic crustal-derived inputs to seawater, and 2) efficient southward marine currents diffusing Arctic unradiogenic waters during periods of high sea levels.

\section{Acknowledgements}

We thank P. Brunet, A. Lanzanova, and M. Henri for technical assistance. The French ANR program "Anox-Sea" financed this work. We also acknowledge support of the Natural Sciences and Engineering Research Council of Canada (P.S), as well as support of the Russian Academy of Science for program no. 1 of the Earth Science Division of RAS, and RFBR grants 13-05-00943 (M.R.), 05-05-64692 (E.P.) and 14-05-00828 (E.P.).

\section{Figure Captions}

Figure 1. Paleogeographic evolution during the Jurassic (simplified from R. Blakey's maps: http://cpgeosystems.com). This includes modifications based on data from van de Meer et al. (2012), Hall (2012), and Seton et al. (2012) for mid-oceanic ridges (black lines) and island arcs (red lines with triangles), Briggs et al. (2004) and Burgess (2008) for the location of North American and southern Gondwanan terranes, as well as Vaughan and Storey (2007) for 
large igneous provinces (yellow) and crustal recycling areas (green dashes). Emergent landmasses are in black, epicontinental domains in light blue, and deep ocean in dark blue. Abbreviations are: An: Antarctica, Ar: Arabian Platform, As: Ashio Belt, Ba: BangongNujiang, Ca: Caples Terrane, CA: Chon Aike, Ch: southern Chile, E: Euro-Boreal, G: Guerrero Terrane, Gh: Ghana, Ju: Junggar, KS: Klamath-Sierra, Lh: Lhasa block, Mi: Mino, Mu: Murihiku, NC: New Caledonia, NM: Northern Mongolia, Pa: Pahau, pT: peri-Tethyan, Q: Quesnellia, Qi: Qiangtang block, Ru: Russian Platform, Ry: Ryoke Belt, Sb: Sub-Boreal, St: Stikinia, Sv: Sverdrup Basin, Ta: Tamba, Tw: Taiwan, V: Viking Corridor, Wa: Waipapa, Wr: Wrangellia, Yf: Yanshan Fold.

Figure 2. Sampling locations represented in current and paleogeographic contexts (Thierry et al., 2000 and R. Blakey's website), and gathered according to broad paleogeographic units. Red and white dots correspond to new and previously published $\varepsilon_{\mathrm{Nd}(\mathrm{t})}$ data, respectively. See supplementary data for exact names of areas reported with numbers. Names of terranes and volcanic areas are indicated in black.

Figure 3. Temporal variations of seawater $\varepsilon_{\mathrm{Nd}(\mathrm{t})}$ values measured in the Euro-Boreal, SubBoreal, peri-Tethyan, Russian, Arabian, and Panthalassan domains. Our new results (filled symbols) are plotted with available published data (empty symbols), and compared with corresponding clastic fraction values. Symbols indicate the different materials and the circled numbers 1 to 6 represent the events discussed in the text. An arbitrary boundary separating radiogenic and unradiogenic signals is drawn at $-7 \varepsilon$-units for comparing the amplitudes of variations. Ages are from Gradstein et al. (2012). Abbreviations: Het: Hettangian, Pliensbach: Pliensbachian, Aal: Aalenian, Baj: Bajocian, Bat: Bathonian, Cal: Callovian, Oxford: Oxfordian, Kimm: Kimmeridgian.

Figure 4. Synthesis of the spatial distribution of $\varepsilon_{\mathrm{Nd}(\mathrm{t})}$ values measured in clastic sediments deposited during the Jurassic. The double colours refer to the maximal and minimal values recorded through time. The paleogeographic map corresponds to a Callovian context (145 Ma). Emergent landmasses and marine shelves are in black and grey, respectively.

Figure 5. Temporal evolution of sedimentary $\varepsilon_{\mathrm{Nd}(\mathrm{t})}$ signals recorded in broad basins from NW Tethyan, Amurian-Asian, Arctic, north American, and southern Gondwanan domains. In order to depict general trends in each domain, the values are enclosed within coloured or 
dashed patterns, which reflect the confidence intervals of data as well as their stratigraphic accuracy. Note that Amurian-Asian data with asterisks are not temporally constrained and are plotted arbitrarily on the left.

Figure 6. Comparison of Jurassic $\varepsilon_{\mathrm{Nd}(\mathrm{t})}$ signatures measured for Panthalassan, Arabian, periTethyan, Russian, and Euro-Boreal surface waters. Box plots represent the median (white line), first and third quartiles (ends of black boxes), as well as minima and maxima (horizonal lines). Jurassic values are also compared to the ranges (represented by medians and quartiles) of modern oceans by using surface water data from Lacan et al. (2012).

Figure 7. Schematic illustration of $\mathrm{Nd}$ sources and diffusion pathways during the Jurassic. Median seawater values are indicated according to the studied marine domains. Surface oceanic circulation (black arrows) is based on numerical simulations of Dera and Donnadieu (2012). Emergent landmasses, marine shelves, and main reliefs are in black, grey, and dashed yellow, respectively.

Figure 8. Temporal correlations between seawater $\varepsilon_{\mathrm{Nd}(\mathrm{t})}$ signals, $\delta^{18} \mathrm{O}$ values, ${ }^{87} \mathrm{Sr} /{ }^{86} \mathrm{Sr}$ variations, sea-level changes, and NW Tethyan volcanic events. ${ }^{87} \mathrm{Sr} /{ }^{86} \mathrm{Sr}$ values are from Jones et al. (1994). $\delta^{18} \mathrm{O}$ data are a compilation of measurements from belemnites collected from NW Tethyan basins, Panthalassan terranes (Haida Gwaii), and the Russian Platform (Podlaha et al., 1998; Gröcke et al., 2007; Price and Rogov, 2009; Dera et al., 2011; Wierzbowski and Rogov, 2011; Wierzbowski et al., 2013). The timing and magnitude of volcanic events (represented by line width) are from Kazmin et al. (1986), van Bergen and Sissingh (2007), and Bergelin (2009). Sea-level changes are from Haq et al. (1988).

Table 1. Compositional, geographical, stratigraphical, and geochemical details of samples measured in this study. Abbreviations for basins: SB: Swabian Basin, NWGB: North West German Basin, WB: Wessex Basin, PB: Paris Basin, RP: Russian Platform, SEB: Sud-Est Basin, WT: Wrangellia Terrane, PT: Peninsular Terrane, ACM: American Cratonic Margin. Footnotes: $\varepsilon_{\mathrm{Nd}(\mathrm{t})}=\left[\left({ }^{143} \mathrm{Nd} /{ }^{144} \mathrm{Nd}\right)_{\text {Sample(t) }} /\left({ }^{143} \mathrm{Nd} /{ }^{144} \mathrm{Nd}\right)_{\mathrm{CHUR}(\mathrm{t})}-1\right] \times 10^{4}$, where $(\mathrm{t})$ is the initial age of deposition based on Gradstein et al. (2012) and CHUR is the referential Chondritic Uniform Reservoir. The initial $\left({ }^{143} \mathrm{Nd} /{ }^{144} \mathrm{Nd}\right)_{(\mathrm{t})}$ of samples and CHUR were calculated by using the radioactive decay of $\mathrm{Sm}$ as follows: $\left({ }^{143} \mathrm{Nd} /{ }^{144} \mathrm{Nd}\right)_{(\mathrm{t})}=\left({ }^{143} \mathrm{Nd} /{ }^{144} \mathrm{Nd}\right)_{(\text {today })}$ $\left[\left({ }^{147} \mathrm{Sm} /{ }^{144} \mathrm{Nd}\right)_{\text {(today) }} \times\left(\exp \left(\lambda_{\mathrm{Sm}} \times \mathrm{t}\right)-1\right)\right]$, where $\left(\lambda_{\mathrm{Sm}}\right)$ is the decay constant for ${ }^{147} \mathrm{Sm}=6.54 \times$ 
$10^{-12} \mathrm{yr}^{-1}$. The initial $\left({ }^{143} \mathrm{Nd} /{ }^{144} \mathrm{Nd}\right)_{\mathrm{CHUR}(\mathrm{t})}$ ratio is calculated using present-day values of $\left({ }^{147} \mathrm{Sm} /{ }^{144} \mathrm{Nd}\right)_{\mathrm{CHUR}}=0.1966$ and $\left({ }^{143} \mathrm{Nd} /{ }^{144} \mathrm{Nd}\right)_{\mathrm{CHUR}}=0.512638$ (Jacobsen and Wasserburg, 1980). The present-day $\left({ }^{147} \mathrm{Sm} /{ }^{144} \mathrm{Nd}\right)_{\text {Sample }}$ is calculated by using ${ }^{147} \mathrm{Sm} /{ }^{144} \mathrm{Nd}=\mathrm{Sm} / \mathrm{Nd} \times$ 0.6049. Note that the elemental concentrations of samples marked with asterisks are not available (analyzed at the Ifremer laboratory, Plouzané, France), and we assume an average ${ }^{147} \mathrm{Sm} /{ }^{144} \mathrm{Nd}$ value of $0.115 \pm 0.02$ (based on our Jurassic database) for $\varepsilon_{\mathrm{Nd}(\mathrm{t})}$ calculations.

\section{References}

Abbink, O., Targarona, J., Brinkhuis, H. and Visscher, H., 2001. Late Jurassic to earliest Cretaceous palaeoclimatic evolution of the southern North Sea. Global and Planetary Change, 30(3-4): 231-256.

Adams, C.J., Pankhurst, R.J., Maas, R. and Millar, I.L., 2005. Nd and Sr isotopic signatures of metasedimentary rocks around the South Pacific margin and implications for their provenance. Journal of the Geological Society, London, Special Publications, 246: 113-141.

Alberti, M., Fursich, F.T. and Pandey, D.K., 2012. The Oxfordian stable isotope record (delta 0-18, delta C-13) of belemnites, brachiopods, and oysters from the Kachchh Basin (western India) and its potential for palaeoecologic, palaeoclimatic, and palaeogeographic reconstructions. Palaeogeography Palaeoclimatology Palaeoecology, 344: 49-68.

Asiedu, D.K., Hegner, E., Rocholl, A. and Atta-Peters, D., 2005. Provenance of Late Ordovician to Early Cretaceous sedimentary rocks from southern Ghana, as inferred from $\mathrm{Nd}$ isotopes and trace elements. Journal of African Earth Sciences, 41: 316-328.

Bailey, T.R., Rosenthal, Y., McArthur, J.M., van de Schootbrugge, B. and Thirlwall, M.F., 2003. Paleoceanographic changes of the Late Pliensbachian-Early Toarcian interval: a possible link to the genesis of an Oceanic Anoxic Event. Earth and Planetary Science Letters, 212(3-4): 307-320.

Baraboshkin, E.J., 2004. Boreal-Tethyan correlation of the Lower Cretaceous ammonite scales. Moscow University Geology Bulletin, 59(6): 9-20.

Barboza-Gudiño, J.R., Orozco-Esquivel, M.T., Gómez-Anguiano, M. and Zavala-Monsiváis, A., 2008. The Early Mesozoic volcanic arc of western North America in northeastern Mexico. Journal of South American Earth Sciences, 25(1): 49-63.

Bartolini, A. and Larson, R.L., 2001. Pacific microplate and the Pangea supercontinent in the Early to Middle Jurassic. Geology, 29(8): 735-738.

Bayon, G., German, C.R., Boella, R.M., Milton, J.A., Taylor, R.N. and Nesbitt, R.W., 2002. An improved method for extracting marine sediment fractions and its application to Sr and Nd isotopic analysis. Chemical Geology, 187(3-4): 179-199.

Bayon, G., Barrat, J.A., Etoubleau, J., Benoit, M., Bollinger, C. and Revillon, S., 2009. Determination of rare earth elements, Sc, Y, Zr, Ba, Hf and Th in geological samples by ICP-MS after Tm addition and alkaline fusion (vol 33, pg 51, 2008). Geostandards and Geoanalytical Research, 33(1): 133-133. 
Bergelin, I., 2009. Jurassic volcanism in Skåne, southern Sweden, and its relation to coeval regional and global events. GFF, 131(1-2): 165-175.

Berner, R.A. and Kothavala, Z., 2001. GEOCARB III: A revised model of atmospheric CO2 over phanerozoic time. American Journal of Science, 301(2): 182-204.

Bjerrum, C.J., Surlyk, F., Callomon, J.H. and Slingerland, R.L., 2001. Numerical paleoceanographic study of the early Jurassic transcontinental Laurasian Seaway. Paleoceanography, 16(4): 390-404.

Bodin, S., Mattioli, E., Fröhlich, S., Marshall, J.D., Boutib, L., Lahsini, S. and Redfern, J., 2011. Toarcian carbon isotope shifts and nutrient changes from the Northern margin of Gondwana (High Atlas, Morocco, Jurassic): palaeoenvironmental implications. Palaeogeography, Palaeoclimatology, Palaeoecology, 297: 377-390.

Boekhout, F., Spikings, R., Sempere, T., Chiaradia, M., Ulianov, A. and Schaltegger, U., 2012. Mesozoic arc magmatism along the southern Peruvian margin during Gondwana breakup and dispersal. Lithos, 146-147: 48-64.

Bonev, N. and Stampfli, G.M., 2008. Petrology, geochemistry and geodynamic implications of Jurassic island arc magmatism as revealed by mafic volcanic rocks in the Mesozoic low-grade sequence, eastern Rhodope, Bulgaria. Lithos, 100: 210233.

Brigaud, B., Puceat, E., Pellenard, P., Vincent, B. and Joachimski, M.M., 2008. Climatic fluctuations and seasonality during the Late Jurassic (Oxfordian-Early Kimmeridgian) inferred from $\delta 180$ of Paris Basin oyster shells. Earth and Planetary Science Letters, 273(1-2): 58-67.

Brigaud, B., Durlet, C., Deconinck, J.F., Vincent, B., Puceat, E., Thierry, J. and Trouiller, A., 2009. Facies and climate/environmental changes recorded on a carbonate ramp: A sedimentological and geochemical approach on Middle Jurassic carbonates (Paris Basin, France). Sedimentary Geology, 222(3-4): 181-206.

Briggs, R.M., Middleton, M.P. and Nelson, C.S., 2004. Provenance history of a Late Triassic-Jurassic Gondwana margin forearc basin, Murihiku Terrane, North Island, New Zealand: petrographic and geochemical constraints. New Zealand Journal of Geology \& Geophysics, 47: 589-602.

Burgess, P.M., 2008. Phanerozoic Evolution of the Sedimentary Cover of the North American Craton. In: A.D. Miall (Editor), The Sedimentary Basins of the United States and Canada. Elsevier.

Cariou, E., Contini, D., Dommergues, J.L., Enay, R., Geyssant, J.R., Mangold, C. and Thierry, J., 1985. Ammonite biogeography and structural evolution of the Tethys during Jurassic time. Bulletin de la Société Géologique de France, 1: 679-697.

Carpentier, C., Martin-Garin, B., Lathuiliere, B. and Ferry, S., 2006. Correlation of reefal Oxfordian episodes and climatic implications in the eastern Paris Basin (France). Terra Nova, 18(3): 191-201.

Cecca, F., Garin, B.M., Marchand, D., Lathuiliere, B. and Bartolini, A., 2005. Paleoclimatic control of biogeographic and sedimentary events in Tethyan and peri-Tethyan areas during the Oxfordian (Late Jurassic). Palaeogeography Palaeoclimatology Palaeoecology, 222(1-2): 10-32.

Channell, J.E.T. and Kozur, H.W., 1997. How many oceans? Meliata, Vardar, and Pindos oceans in Mesozoic Alpine paleogeography. Geology, 25(2): 183-186.

Charbonnier, G., Puceat, E., Bayon, G., Desmares, D., Dera, G., Durlet, C., Deconinck, J.F., Amedro, F., Gourlan, A.T., Pellenard, P. and Bomou, B., 2012. Reconstruction of the $\mathrm{Nd}$ isotope composition of seawater on epicontinental seas: Testing the 
potential of Fe-Mn oxyhydroxide coatings on foraminifera tests for deep-time investigations. Geochimica et Cosmochimica Acta, 99: 39-56.

Chyi, M.S., Crerar, D.A., Carlson, R.W. and Stallard, R.F., 1984. Hydrothermal Mn-deposits of the Franciscan Assemblage, II. Isotope and trace element geochemistry, and implications for hydrothermal convection at spreading centers. Earth and Planetary Science Letters, 71(1): 31-45.

Clift, P.D., Draut, A.E., Kelemen, P.B., Blusztajn, J. and Greene, A., 2005. Stratigraphic and geochemical evolution of an oceanic arc upper crustal section: The Jurassic Talkeetna Volcanic Formation, south-central Alaska. Geological Society of America Bulletin, 117(7-8): 902-925.

Coffin, M.F. and Eldhoom, O., 1992. Volcanism and continental break-up: a global compilation of large ingeous provinces. Geological Society Special Publication, 68: 17-30.

Cogné, J.P., Kravchinsky, V.A., Halim, N. and Hankard, F., 2005. Late Jurassic-Early Cretaceous closure of the Mongol-Okhotsk Ocean demonstrated by new Mesozoic palaeomagnetic results from the Trans-Baikal area (SE Siberia). Geophysical Journal International, 163(2): 813-832.

Cohen, A.S., Coe, A.L., Bartlett, J.M. and Hawkesworh, C.J., 1999. Precise Re-Os ages of organic-rich mudrocks and the Os isotope composition of Jurassic seawater. Earth and Planetary Science Letters, 167(3-4): 159-173.

Cohen, A.S., Harding, S.M., Coe, A.L. and Schwark, L., 2002. Isotopic and geochemical evidence for changes in global weathering during the Toarcian OAE. Geochimica et Cosmochimica Acta, 66(15A): A147-A147.

Davies, G., Gledhill, A. and Hawkesworh, C., 1985. Upper crustal recycling in southern Britain: evidence from $\mathrm{Nd}$ and $\mathrm{Sr}$ isotopes. Earth and Planetary Science Letters, 75: 1-12.

DeBari, S.M., Anderson, R.G. and Mortensen, J.K., 1999. Correlation among lower to upper crustal components in an island arc: the Jurassic Bonanza arc, Vancouver Island, Canada. Canadian Journal of Earth Sciences, 36: 1371-1413.

DePaolo, D.J., 1988. Neodymium isotope geochemistry. Springer-Verlag, New York.

Dera, G., Pellenard, P., Neige, P., Deconinck, J.F., Puceat, E. and Dommergues, J.L., 2009a. Distribution of clay minerals in Early Jurassic Peritethyan seas: Palaeoclimatic significance inferred from multiproxy comparisons. Palaeogeography Palaeoclimatology Palaeoecology, 271(1-2): 39-51.

Dera, G., Pucéat, E., Pellenard, P., Neige, P., Delsate, D., Joachimski, M.M., Reisberg, L. and Martinez, M., 2009b. Water mass exchange and variations in seawater temperature in the NW Tethys during the Early Jurassic: Evidence from neodymium and oxygen isotopes of fish teeth and belemnites. Earth and Planetary Science Letters, 286(1-2): 198-207.

Dera, G., Brigaud, B., Monna, F., Laffont, R., Pucéat, E., Deconinck, J.-F., Pellenard, P., Joachimski, M.M. and Durlet, C., 2011. Climatic ups and downs in a disturbed Jurassic world. Geology, 39: 215-218.

Dera, G. and Donnadieu, Y., 2012. Modeling evidences for global warming, Arctic seawater freshening, and sluggish oceanic circulation during the Early Toarcian anoxic event. Paleoceanography, 27.

Dickinson, W.R. and Gehrels, G.E., 2010. Insights into North American paleogeography and paleotectonics from $\mathrm{U}-\mathrm{Pb}$ ages of detrital zircons in Mesozoic strata of the Colorado Plateau, USA. International Journal of Earth Sciences, 99: 1247-1265. 
Dokuz, A., Karsli, O., Chen, B. and Uysal, I., 2010. Sources and petrogenesis of Jurassic granitoids in the Yusufeli area, Northeastern Turkey: Implications for pre- and post-collisional lithospheric thinning of the eastern Pontides. Tectonophysics, 480: 259-279.

Donnadieu, Y., Godderis, Y., Pierrehumbert, R., Dromart, G., Fluteau, F. and Jacob, R., 2006. A GEOCLIM simulation of climatic and biogeochemical consequences of Pangea breakup. Geochemistry Geophysics Geosystems, 7.

Dopieralska, J., Belka, Z., Koenigshof, P., Racki, G., Savage, N., Lutat, P. and Sardsud, A., 2012. Nd isotopic composition of Late Devonian seawater in western Thailand: Geotectonic implications for the origin of the Sibumasu terrane. Gondwana Research, 22(3-4): 1102-1109.

Doré, A.G., 1991. The structural foundation and evolution of Mesozoic seaways between Europe and the Arctic. Palaeogeography, Palaeoclimatology, Palaeoecology, 87(14): 441-492.

Dypvik, H. and Zakharov, V.A., 2012. Late Jurassic-Early Cretaceous fine-grained epicontinental arctic sedimentation - mineralogy and geochemistry of shales from the Late Jurassic - Early Cretaceous transition. Norwegian Journal of Geology, 92: 65-87.

Ehrenberg, S.N., Dalland, A., Nadeau, P.H., Mearns, E.W. and Amundsen, H.E.F., 1998. Origin of chlorite enrichment and neodymium isotopic anomalies in Haltenbanken sandstones. Marine and Petroleum Geology, 15(403-425).

Féraud, G., Alric, V., Fornari, M., Bertrand, H. and Haller, M., 1999. Ar-40/Ar-39 dating of the Jurassic volcanic province of Patagonia: migrating magmatism related to Gondwana break-up and subduction. Earth and Planetary Science Letters, 172(12): 83-96.

Frakes, L.A., Francis, J.E. and Syktus, J.I., 1992. Climate modes of the Phanerozoic. Cambridge University Press, New York.

Frank, N., 2002. Radiogenic isotopes: tracers of past ocean circulation and erosional input. Reviews of Geophysics, 40(1): 1-38.

Frost, C.D. and Coombs, D.S., 1989. Nd isotope character of new Zealand sediments: Implications for terrane concepts and crustal evolution. American Journal of Science, 289: 744-770.

Fu, X., Wang, J., Zeng, Y., Tan, F. and Feng, X., 2012. Sources regions and the sedimentary paleoenvironment of marine oil shale from the Bilong Co area, northern Tibet, China: a Sr-Nd isotopic study. Oil shale, 29(4): 306-321.

Gaina, C., Torsvik, T.H., van Hinsbergen, D.J.J., Medvedev, S., Werner, S.C. and Labails, C., 2013. The African Plate: A history of oceanic crust accretion and subduction since the Jurassic. Tectonophysics, in press.

Goldstein, S. and Jacobsen, S.B., 1987. The Nd and Sr isotopic systematics of river-water dissolved material: implications for the sources of $\mathrm{Nd}$ and $\mathrm{Sr}$ in the seawater. Chemical Geology, 66: 245-272.

Goldstein, S. and Hemming, S.R., 2003. Long lived isotopic tracers in oceanography, paleoceanography and ice-sheet dynamics, Treatise on Geochemistry. Elsevier, New York, pp. 453-489.

Gradstein, F.M., Ogg, J.G., Schmitz, M. and Ogg, G., 2012. The Geological Time Scale 2012. Elsevier.

Grandjean, P., Cappetta, H., Michard, A. and Albarède, F., 1987. The assessment of REE patterns and $143 \mathrm{Nd} / 144 \mathrm{Nd}$ ratios in fish remains. Earth and Planetary Science Letters, 84(2-3): 181-196. 
Gröcke, D.R., Hesselbo, S.P. and Findlay, D.J., 2007. Atypical diagenetic effects on strontium-isotope composition of Early Jurassic belemnites, Queen Charlotte Islands, British Columbia, Canada. Canadian Journal of Earth Sciences, 44(2): 181-197.

Hall, R., 2012. Late Jurassic-Cenozoic reconstructions of the Indonesian region and the Indian Ocean. Tectonophysics, 570-571: 1-41.

Haq, B.U., Hardenbol, J. and Vail, P.R., 1988. Mesozoic and Cenozoic chronostratigraphy and cycles of sea-level change. SEPM special publications, 42: 71-108.

Hesselbo, S.P., Deconinck, J.F., Huggett, J.M. and Morgans Bell, H.S., 2009. Late Jurassic palaeoclimatic change from clay mineralogy and gamma-ray spectrometry of the Kimmeridge Clay, Dorset, UK. Journal of the Geological Society, London, 166: 1123-1133.

Horikawa, K., Martin, E.E., Asahara, Y. and Sagawa, T., 2011. Limits on conservative behavior of $\mathrm{Nd}$ isotopes in seawater assessed from analysis of fish teeth from Pacific core tops. Earth and Planetary Science Letters, 310(1-2): 119-130.

Hotinski, R.M. and Toggweiler, J.R., 2003. Impact of a Tethyan circumglobal passage on ocean heat transport and "equable" climates. Paleoceanography, 18(1): 1007.

Jacobsen, S.B. and Wasserburg, G.J., 1980. Sm-Nd isotopic evolution of chondrites. Earth and Planetary Science Letters, 50(1): 139-155.

Jeandel, C., Arsouze, T., Lacan, F., Techine, P. and Dutay, J.C., 2007. Isotopic Nd compositions and concentrations of the lithogenic inputs into the ocean: A compilation, with an emphasis on the margins. Chemical Geology, 239(1-2): 156164.

Jenkyns, H.C., Jones, C.E., Grocke, D.R., Hesselbo, S.P. and Parkinson, D.N., 2002. Chemostratigraphy of the Jurassic System: applications, limitations and implications for palaeoceanography. Journal of the Geological Society, 159: 351378.

Jones, C.E., Jenkyns, H.C., Coe, A.L. and Hesselbo, S.P., 1994. Strontium isotopic variations in Jurassic and Cretaceous seawater. Geochimica et Cosmochimica Acta, 58(14): 3061-3074.

Kagami, H., Kawano, Y., Akiyama, M., Ikawa, T., Imaoka, T., Ishioka, J., Toyoshima, T., Hamamoto, T., Hayasaka, Y., Ikeda, Y., Yuhara, M. and Tainosho, Y., 2006. Provenance of Paleozoic-Mesozoic sedimentary rocks in the Inner Zone of Southwest Japan: An evaluation based on Nd model ages. Gondwana Research, 2006: 142-151.

Kalnins, L.M. and Watts, A.B., 2009. Spatial variations in effective elastic thickness in the Western Pacific Ocean and their implications for Mesozoic volcanism. Earth and Planetary Science Letters, 286: 89-100.

Kazmin, V.G., Sbortshikov, I.M., Ricou, L.E., Zonenshain, L.P., Boulin, J. and Knipper, A.L., 1986. Volcanic belts as markers of the Mesozoic-Cenozoic active margin of Eurasia. Tectonophysics, 123(1-4): 123-152.

Keto, L.S. and Jacobsen, S.B., 1988. Nd isotopic variations of Phanerozoic paleoceans. Earth and Planetary Science Letters, 90(4): 395-410.

Kocsis, L., Trueman, C.N. and Palmer, M.R., 2010. Protracted diagenetic alteration of REE contents in fossil bioapatites: Direct evidence from $\mathrm{Lu}-\mathrm{Hf}$ isotope systematics. Geochimica Cosmochimica Acta, 74(21): 6077-6092.

Labails, C., Olivet, J.L., Aslanian, D. and Roest, W.R., 2010. An alternative early opening scenario for the Central Atlantic Ocean. Earth and Planetary Science Letters, 297(3-4): 355-368. 
Lacan, F. and Jeandel, C., 2005. Neodymium isotopes as a new tool for quantifying exchange fluxes at the continent-ocean interface. Earth and Planetary Science Letters, 232(3-4): 245-257.

Lacan, F., Tachikawa, K. and Jeandel, C., 2012. Neodymium isotopic composition of the oceans: A compilation of seawater data. Chemical Geology, 300: 177-184.

Lan, C.Y., Lee, C.S., Shen, J.J.S., Lu, C.Y., Mertzman, S.A. and Wu, T.W., 2002. Nd-Sr isotopic composition and geochemistry of sediments from Taiwan and their implications. Western Pacific Earth Sciences, 2(2): 205-222.

Lézin, C., Andreu, B., Pellenard, P., Bouchez, J.L., Emmanuel, L., Fauré, P. and Landrein, P., 2013. Geochemical disturbance and paleoenvironmental changes during the Early Toarcian in NW Europe. Chemical Geology, 341: 1-15.

Liew, T.C. and Hofmann, A.W., 1988. Precambrian crustal components, plutonic associations, plate environment of the Hercynian Fold Belt of central Europe: Indications from a $\mathrm{Nd}$ and $\mathrm{Sr}$ isotopic study. Contributions to Mineralogy and Petrology, 98(129-138).

Louis-Schmid, B., Rais, P., Schaeffer, P., Bernasconi, S.M. and Weissert, H., 2007. Plate tectonic trigger of changes in pCO2 and climate in the Oxfordian (Late Jurassic): Carbon isotope and modeling evidence. Earth and Planetary Science Letters, 258(1-2): 44-60.

Mahlen, N.J., Johnson, C.M., Baumgartner, L.P. and Beard, B.L., 2005. Provenance of Jurassic Tethyan sediments in the HP/UHP Zermatt-Saas ophiolite, western Alps. Geological Society of America Bulletin, 117(3-4): 530-544.

Malfilatre, C., Boulvais, P., Dabard, M.P., Bourquin, S., Hallot, E., Pallix, D. and Gapais, D., 2012. Petrographical and geochemical characterization of Comblanchien limestone (Bourgogne, France): A fingerprint of the building stone provenance. Comptes Rendus Geoscience, 344(1): 14-24.

Martin, E.E. and Scher, H.D., 2004. Preservation of seawater Sr and Nd isotopes in fossil fish teeth: bad news and good news. Earth and Planetary Science Letters, 220(12): 25-39.

Martin, E.E., Blair, S.W., Kamenov, G.D., Scher, H.D., Bourbon, E., Basak, C. and Newkirk, D.N., 2010. Extraction of $\mathrm{Nd}$ isotopes from bulk deep sea sediments for paleoceanographic studies on Cenozoic time scales. Chemical Geology, 269: 414431.

Martin, E.E., MacLeod, K.G., Berrocoso, A.J. and Bourbon, E., 2012. Water mass circulation on Demerara Rise during the Late Cretaceous based on $\mathrm{Nd}$ isotopes. Earth and Planetary Science Letters, 327: 111-120.

Martin-Garin, B., Lathuiliere, B., Geister, J. and Ramseyer, K., 2010. Oxygen isotopes and climatic control of Oxfordian coral reefs (Jurassic, Tethys). Palaios, 25(11-12): 721-729.

Martin-Garin, B., Lathuiliere, B. and Geister, J., 2012. The shifting biogeography of reef corals during the Oxfordian (Late Jurassic). A climatic control? Palaeogeography Palaeoclimatology Palaeoecology, 365: 136-153.

McArthur, J.M., Donovan, D.T., Thirlwall, M.F., Fouke, B.W. and Mattey, D., 2000. Strontium isotope profile of the early Toarcian (Jurassic) oceanic anoxic event, the duration of ammonite biozones, and belemnite palaeotemperatures. Earth and Planetary Science Letters, 179(2): 269-285.

McLeod, K.G., Martin, E.E. and Blair, S.W., 2008. Nd isotopic excursion across Cretaceous ocean anoxic event 2 (Cenomanian-Turonian) in the tropical North Atlantic. Geology, 36(10): 811-814. 
Mearns, E.W., 1989. Neodymium isotope stratigraphy of Gullfaks oilfield. In: J.D. Collinson (Editor), Correlation in hydrocarbon exploration. Graham \& Trotman Inc., pp. 201-215.

Mearns, E.W., Knarud, R., Raestad, N., Stanley, K.O. and Stockbridge, C.P., 1989. Samarium-neodymium isotope stratigraphy of the Lunde and Statfjord Formations of Snorre Oil Field, northern North Sea. Journal of the Geological Society, London, 146: 217-228.

Meijers, M.J.M., Vrouwe, B., van Hinsbergen, D.J.J., Kuiper, K.F., Wijbrans, J., Davies, G.R., Stephenson, R.A., Kaymakci, N., Matenco, L. and Saintot, A., 2010. Jurassic arc volcanism on Crimea (Ukraine): Implications for the paleo-subduction zone configuration of the Black Sea region. Lithos, 412-426.

Meinhold, G., Morton, A.C., Fanning, C.M., Frei, D., Howard, J.P., Phillips, R.J., Strogen, D. and Whitham, A.G., 2011. Evidence from detrital zircons for recycling of Mesoproterozoic and Neoproterozoic crust recorded in Paleozoic and Mesozoic sandstones of southern Libya. Earth and Planetary Science Letters, 312: 164-175.

Michard, A., Gurriet, P., Soudant, M. and Albarède, F., 1985. Nd isotopes in French Phanerozoic shales - External vs. internal aspects of crustal evolution. Geochimica Cosmochimica Acta, 49(601-610).

Moiroud, M., Pucéat, E., Donnadieu, Y., Bayon, G., Moriya, K., Deconinck, J.F. and Boyet, M., 2013. Evolution of the neodymium isotopic signature of neritic seawater on a northwestern Pacific margin: new constrains on possible end-members for the composition of deep-water masses in the Late Createous ocean. Chemical Geology, 356: 160-170.

Monger, J.W.H., Price, R.A. and Tempelman-Kluit, D.J., 1982. Tectonic accretion and the origin of the two metamorphic and plutonic welts in the Canadian Cordillera. Geology, 10: 70-75.

Morton, A., Hallsworth, C., Strogen, D., Whitham, A. and Fanning, M., 2009. Evolution of provenance in the NE Atlantic rift: The Early-Middle Jurassic succession in the Heidrun Field, Halten Terrace, offshore Mid-Norway. Marine and Petroleum Geology, 26: 1100-1117.

Négrel, P., Casanova, J. and Brulhet, J., 2006. REE and Nd Isotope Stratigraphy of a Late Jurassic Carbonate Platform, Eastern Paris Basin, France. Journal of Sedimentary Research, 76(3): 605-617.

Nozaki, T., Kato, Y. and Suzuki, K., 2013. Late Jurassic ocean anoxic event: evidence from voluminous sulphide deposition and preservation in the Panthalassa. Scientific Reports, 3: 1889.

Nunn, E.V., Price, G.D., Hart, M.B., Page, K.N. and Leng, M.J., 2009. Isotopic signals from Callovian-Kimmeridgian (Middle-Upper Jurassic) belemnites and bulk organic carbon, Staffin Bay, Isle of Skye, Scotland. Journal of the Geological Society, 166: 633-641.

Olivier, N. and Boyet, M., 2006. Rare earth and trace elements of microbialites in Upper Jurassic coral- and sponge-microbialite reefs. Chemical Geology, 230(1-2): 105123.

Padden, M., Weissert, H. and de Rafelis, M., 2001. Evidence for Late Jurassic release of methane from gas hydrate. Geology, 29(3): 223-226.

Patchett, P.J. and Gehrels, G.E., 1998. Continental influence on Canadian cordilleran terranes from $\mathrm{Nd}$ Isotope study, and significance for crustal growth processes. The Journal of Geology, 106(3): 269-280. 
Patchett, P.J., Ross, G.M. and Gleason, J.D., 1999. Continental drainage and mountain sources during the Phanerozoic evolution of North America: evidence from $\mathrm{Nd}$ isotopes. Science, 283: 671-673.

Patchett, P.J., Embry, A.F., Ross, G.M., Beauchamp, B., Harrison, J.C., Mayr, U., Isachsen, C.E., Rosenberg, E.J. and Spence, G.O., 2004. Sedimentary cover of the Canadian Shield through Mesozoic time reflected by $\mathrm{Nd}$ isotopic and geochemical results for the Sverdrup Basin, Arctic Canada. The Journal of Geology, 112: 39-57.

Pearce, C.R., Jones, M.T., Oelkers, E.H., Pradoux, C. and Jeandel, C., 2013. The effect of particulate dissolution on the neodymium (Nd) isotope and Rare Earth Element (REE) composition of seawater. Earth and Planetary Science Letters, 369-370: 138-147.

Petersen, N.T., Smith, P.L., Mortensen, J.K., Creaser, R.A. and Tipper, H.W., 2004. Provenance of Jurassic sedimentary rocks of south-central Quesnellia, British Columbia: implications for paleogeography. Canadian Journal of Earth Sciences, 41: 103-125.

Podlaha, O.G., Mutterlose, J. and Veizer, J., 1998. Preservation of delta 180 and delta 13C in belemnite rostra from the Jurassic/Early Cretaceous successions. American Journal of Science, 298(4): 324-347.

Price, G.D., 1999. The evidence and implications of polar ice during the Mesozoic. EarthScience Reviews, 48(3): 183-210.

Price, G.D. and Rogov, M.A., 2009. An isotopic appraisal of the Late Jurassic greenhouse phase in the Russian Platform. Palaeogeography Palaeoclimatology Palaeoecology, 273(1-2): 41-49.

Pucéat, E., Lecuyer, C. and Reisberg, L., 2005. Neodymium isotope evolution of NW Tethyan upper ocean waters throughout the Cretaceous. Earth and Planetary Science Letters, 236(3-4): 705-720.

Rais, P., Louis-Schmid, B., Bernasconi, S.M. and Weissert, H., 2007. Palaeoceanographic and palaeoclimatic reorganization around the Middle-Late Jurassic transition. Palaeogeography Palaeoclimatology Palaeoecology, 251(3-4): 527-546.

Ricketts, B.D., 2008. Cordilleran Sedimentary Basins of Western Canada Record 180 Million Years of Terrane Accretion. In: A.D. Miall (Editor), The Sedimentary Basins of the United States and Canada. Elsevier, pp. 363-394.

Rogov, M.A., Zakharov, V. and Kiselev, D., 2008. Molluscan immigrations via biogeographical ecotone of the Middle Russian Sea during the Jurassic. Volumina Jurassica, 6(6): 143-152.

Rogov, M.A. and Zakharov, V., 2010. Jurassic and Lower Cretaceous glendonite occurences and their implication for Arctic Plaeoclimate reconstructions and stratigraphy. Earth Science Frontiers, 17 (Special issue): 345-346.

Rogov, M.A., 2012. Latitudinal gradient of taxonomic richness of ammonites in the Kimmeridgian-Volgian in the northern hemisphere. Paleontological Journal, 46(2): 148-156.

Rosales, I., Quesada, S. and Robles, S., 2004. Paleotemperature variations of Early Jurassic seawater recorded in geochemical trends of belemnites from the BasqueCantabrian basin, northern Spain. Palaeogeography, Palaeoclimatology, Palaeoecology, 203(3-4): 253-275.

Scher, H.D. and Martin, E.E., 2004. Circulation in the Southern Ocean during the Paleogene inferred from neodymium isotopes. Earth and Planetary Science Letters, 228: 391-405. 
Şen, C., 2007. Jurassic Volcanism in the Eastern Pontides: Is it Rift Related or Subduction Related? Turkish Journal of Earth Sciences, 16: 523-539.

Seton, M., Müller, R.D., Zahirovic, S., Gaina, C., Torsvik, T.H., Shephard, G., Talsma, A., Gurnis, M., Turner, M., Maus, S. and Chandler, M., 2012. Global continental and ocean basin reconstructions since 200 Ma. Earth-Science Reviews, 113(3-3): 212270.

Sey, I.I., Repin, S., Kalacheva, E.D., Okuneva, T.M., Paraketsov, K.V. and Polubotko, I.V., 1992. Eastern Russia. In: G.E.G. Westermann (Editor), The Jurassic of the CircumPacific. Cambridge University Press, Cambridge, pp. 225-245.

Shaw, H.F. and Wasserburg, G.J., 1984. Isotopic constraints on the origin of Appalachian mafic complexes. American Journal of Science, 284: 319-349.

Shaw, H.F. and Wasserburg, G.J., 1985. Sm-Nd in marine carbonates and phosphates: Implications for $\mathrm{Nd}$ isotopes in seawater and crustal ages. Geochimica Cosmochimica Acta, 49(2): 503-518.

Sidorczuk, M., Lewandowski, M., Bełka, Z. and Nejbert, K., 2010. Isotopic and paleomagnetic studies of the Middle and Upper Jurassic carbonates in the Pieniny Klippen Belt: environmental and paleogeographic implications for the Northern Tethys. Geologia balcanica, 39(1-2): 361-361.

Silva, R.L., Duarte, L.V., Comas-Rengifo, M.J., Mendonça Filho, J.G. and Azerêdo, A.C., 2011. Update of the carbon and oxygen isotopic records of the Early-Late Pliensbachian (Early Jurassic, $187 \mathrm{Ma}$ ): Insights from the organic-rich hemipelagic series of the Lusitanian Basin (Portugal). Chemical Geology, 283(3-4): 177-184.

Sjostrom, D.J., Hendrix, M.S., Badamgarav, D., Graham, S.A. and Nelson, B.K., 2001. Sedimentology and provenance of Mesozoic nonmarine strata in western Mongolia: A record of intracontinental deformation. Geological Society of America Memoirs, 194: 361-388.

Soudry, D., Glenn, C.R., Nathan, Y., Segal, I. and VonderHaar, D., 2006. Evolution of Tethyan phosphogenesis along the northern edges of the Arabian-African shield during the Cretaceous-Eocene as deduced from temporal variations of $\mathrm{Ca}$ and $\mathrm{Nd}$ isotopes and rates of $\mathrm{P}$ accumulation. Earth-Science Reviews, 78(1-2): 27-57.

Stille, P., Clauer, N. and Abrecht, J., 1989. Nd isotopic composition of Jurassic Tethys seawater and the genesis of Alpine Mn-deposits: Evidence from Sr-Nd isotope data. Geochimica Cosmochimica Acta, 53(5): 1095-1099.

Stille, P. and Fischer, H., 1990. Secular variation in the isotopic composition of $\mathrm{Nd}$ in Tethys seawater. Geochimica Cosmochimica Acta, 54(11): 3139-3145.

Stille, P., Steinmann, M. and Riggs, S.R., 1996. Nd isotope evidence for the evolution of the paleocurrents in the Atlantic and Tethys Oceans during the past $180 \mathrm{Ma}$. Earth and Planetary Science Letters, 144(1-2): 9-19.

Tachikawa, K., Athias, V. and Jeandel, C., 2003. Neodymium budget in the modern ocean and paleo-oceanographic implications. Journal of Geophysical Research-Oceans, 108(C8).

Thierry, J., Barrier, E. and co-authors, 2000. Middle Callovian. In: J. Dercourt, M. Gaetani, B. Vrielynck, E. Barrier, B. Biju-Duval, M.-F. Brunet, J.P. Cadet, S. Crasquin and M. Sandulescu (Editors), Atlas Peri-Tethys, Paleogeographical maps Paris, pp. 9.

Thomas, D.J., Bralower, T.J. and Jones, C.E., 2003. Neodymium isotopic reconstruction of late Paleocene-early Eocene thermohaline circulation. Earth and Planetary Science Letters, 209(3-4): 309-322. 
Tütken, T., Vennemann, T.W. and Pfretzschner, H.U., 2011. Nd and Sr isotope compositions in modern and fossil bones - Proxies for vertebrate provenance and taphonomy. Geochimica Cosmochimica Acta, 75: 5951-5970.

Underhill, J.R. and Partington, M.A., 1993. Jurassic thermal doming and deflation in the North Sea: implications of the sequence stratigraphic evidence. Geological Society, London, Petroleum Geology Conferences series, 4: 337-345.

van Bergen, M.J. and Sissingh, W., 2007. Magmatism in the Netherlands: expression of the north-west European rifting history. In: T.E. Wong, D.A. Batjes and J. de Jager (Editors), Geology of the Netherlands. Royal Netherlands Academy of Arts and Sciences, pp. 197-221.

van de Schootbrugge, B., Bailey, T.R., Rosenthal, Y., Katz, M.E., Wright, J.D., Miller, K.G., Feist-Burkhardt, S. and Falkowski, P.G., 2005. Early Jurassic climate change and the radiation of organic-walled phytoplankton in the Tethys Ocean. Paleobiology, 31(1): 73-97.

van der Meer, D.G., Torsvik, T.H., Spakman, W., van Hinsbergen, D.J.J. and Amaru, M.L., 2012. Intra-Panthalassa Ocean subduction zones revealed by fossil arcs and mantle structure. Nature Geoscience, 5(3): 215-219.

Vaughan, A.P.M. and Storey, B.C., 2007. A new supercontinent self-destruct mechanism: evidence from the Late Triassic-Early Jurassic. Journal of the Geological Society, London, 164: 383-392.

Wang, Y., Fan, W., Zhang, G. and Zhang, Y., 2013. Phanerozoic tectonics of the South China Block: Key observations and controversies. Gondwana Research, 23: 12731305.

Weissert, H. and Mohr, H., 1996. Late Jurassic climate and its impact on carbon cycling. Palaeogeography Palaeoclimatology Palaeoecology, 122: 27-43.

Wierzbowski, H., 2004. Carbon and oxygen isotope composition of Oxfordian-Early Kimmeridgian belemnite rostra: palaeoenvironmental implications for Late Jurassic seas. Palaeogeography Palaeoclimatology Palaeoecology, 203(1-2): 153168.

Wierzbowski, H. and Rogov, M.A., 2011. Reconstructing the palaeoenvironment of the Middle Russian Sea during the Middle-Late Jurassic transition using stable isotope ratios of cephalopod shells and variations in faunal assemblages. Palaeogeography Palaeoclimatology Palaeoecology, 299(1-2): 250-264.

Wierzbowski, H., Rogov, M.A., Matyja, B.A., Kiselev, D. and Ippolitov, A., 2013. MiddleUpper Jurassic (Upper Callovian-Lower Kimmeridgian) stable isotope and elemental records of the Russian Platform: Indices of oceanographic and climatic changes. Global and Planetary Change, 107: 196-212.

Wilson, D.J., Piotrowski, A.M., Galy, A. and Clegg, J.A., 2013. Reactivity of neodymium carriers in deep sea sediments: Implications for boundary exchange and paleoceanography. Geochimica Cosmochimica Acta, 109: 197-221.

Woodard, S.C., Thomas, D.J., Grossman, E.L., Olszewski, T.D., Yancey, T.E., Miller, B.V. and Raymond, A., 2013. Radiogenic isotope composition of Carboniferous seawater from North American epicontinental seas. Palaeogeography Palaeoclimatology Palaeoecology, 370: 51-63.

Xie, S., Y., W., Gao, S., Liu, X., Zhou, L., Zhao, L. and Hu, Z., 2012. Sr-Nd isotopic and geochemical constraints on provenance of late Paleozoic to early Cretaceous sedimentary rocks in the Western Hills of Beijing, North China: Implications for the uplift of the northern North China Craton. Sedimentary Geology, 245-246: 1728. 
Yang, J., Cawood, P.A. and Du, Y., 2010. Detrital record of mountain building: Provenance of Jurassic foreland basin to the Dabie Mountains. Tectonics, 29: TC4011.

Zhang, K.J., Tang, X.C., Wang, Y. and Zhang, Y.X., 2011. Geochronology, geochemistry, and $\mathrm{Nd}$ isotopes of early Mesozoic bimodal volcanism in northern Tibet, western China: Constraints on the exhumation of the central Qiangtang metamorphic belt. Lithos, 121: 167-175.

Zheng, X.Y., Jenkyns, H.C., Gale, A.S., Ward, D.J. and Henderson, G.M., 2013. Changing ocean circulation and hydrothermal inputs during Ocean Anoxic Event 2 (Cenomanian-Turonian): Evidence from $\mathrm{Nd}$-isotopes in the European shelf sea. Earth and Planetary Science Letters, 375: 338-348. 

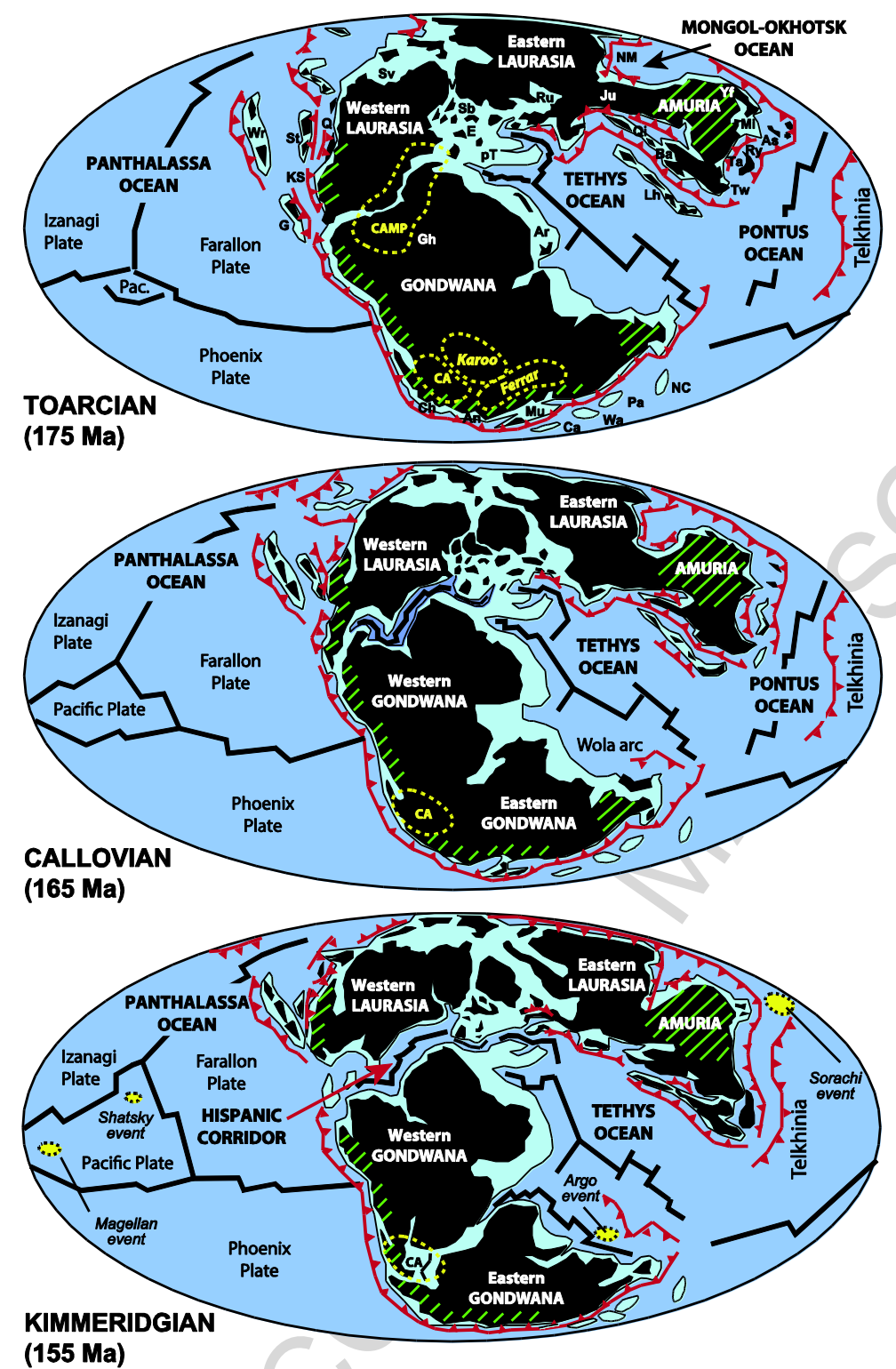

Fig 1 

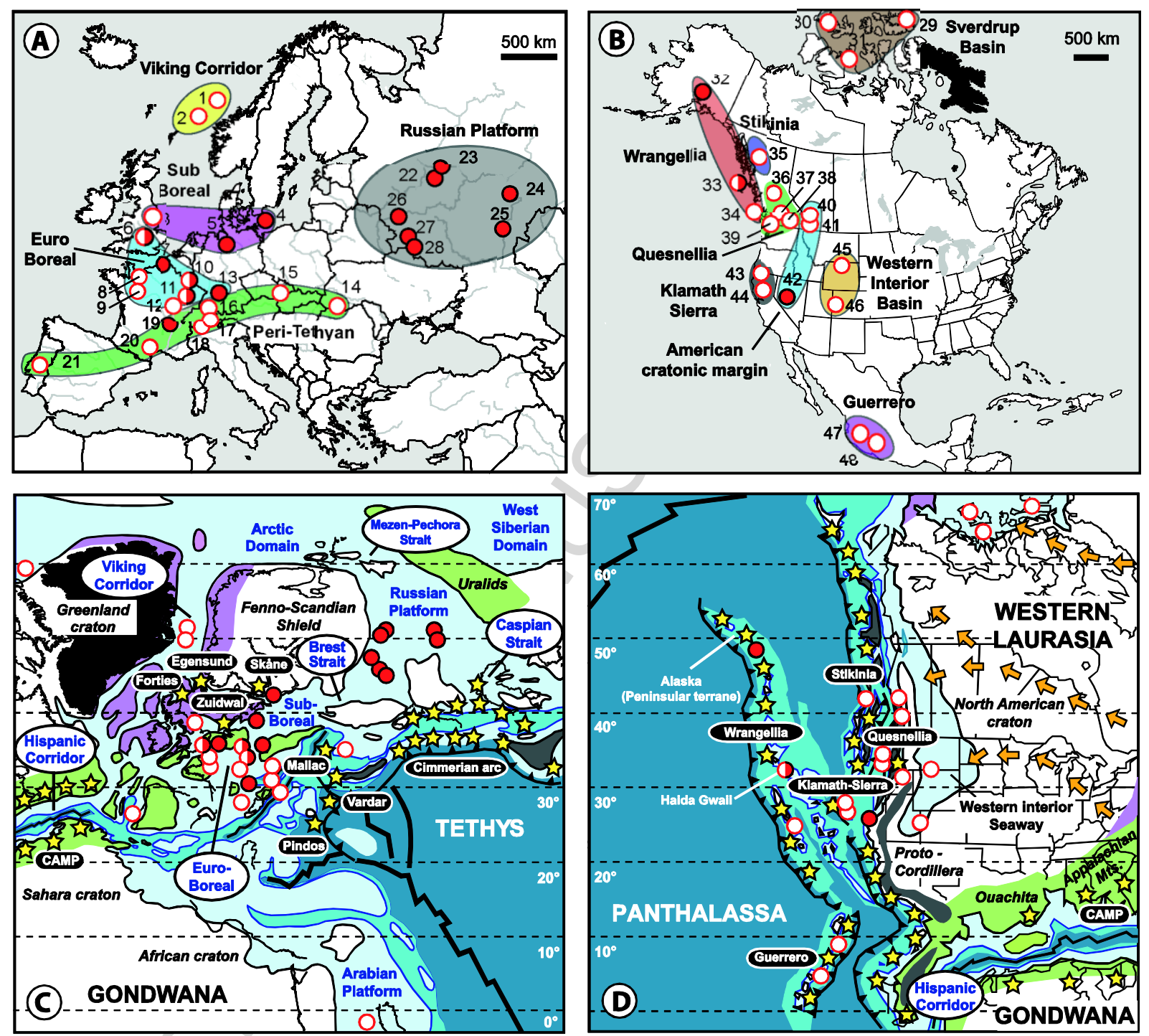

$\square$ Precambrian crust $\square$ Shallow marine environments

Young subduction

馆 Jurassic volcanism

Data from this study Caledonian crust Deep marine environments

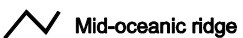

Sedimentary inputs Data from literature

Fig 2 Hercynian crust 


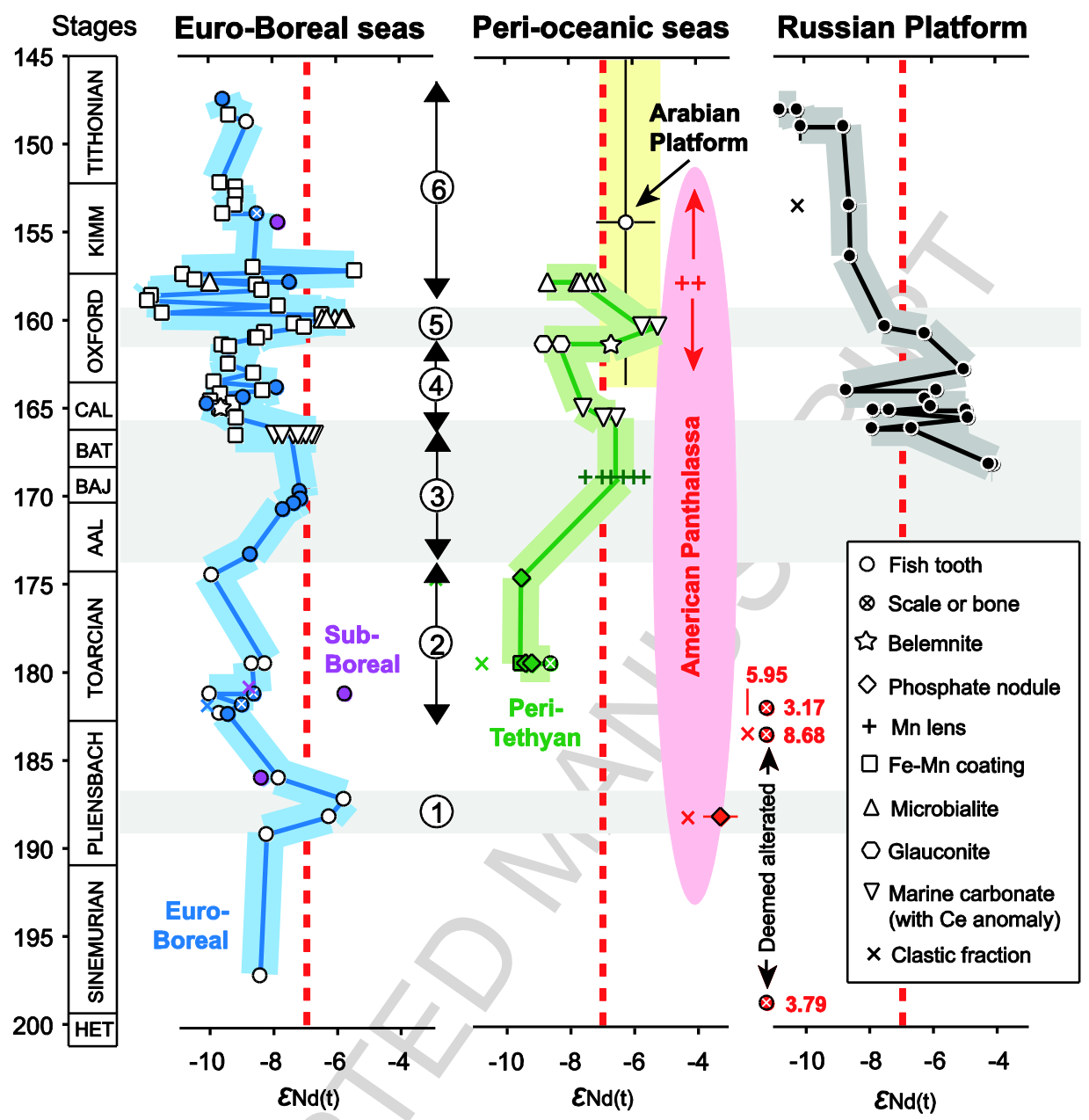

Fig 3 


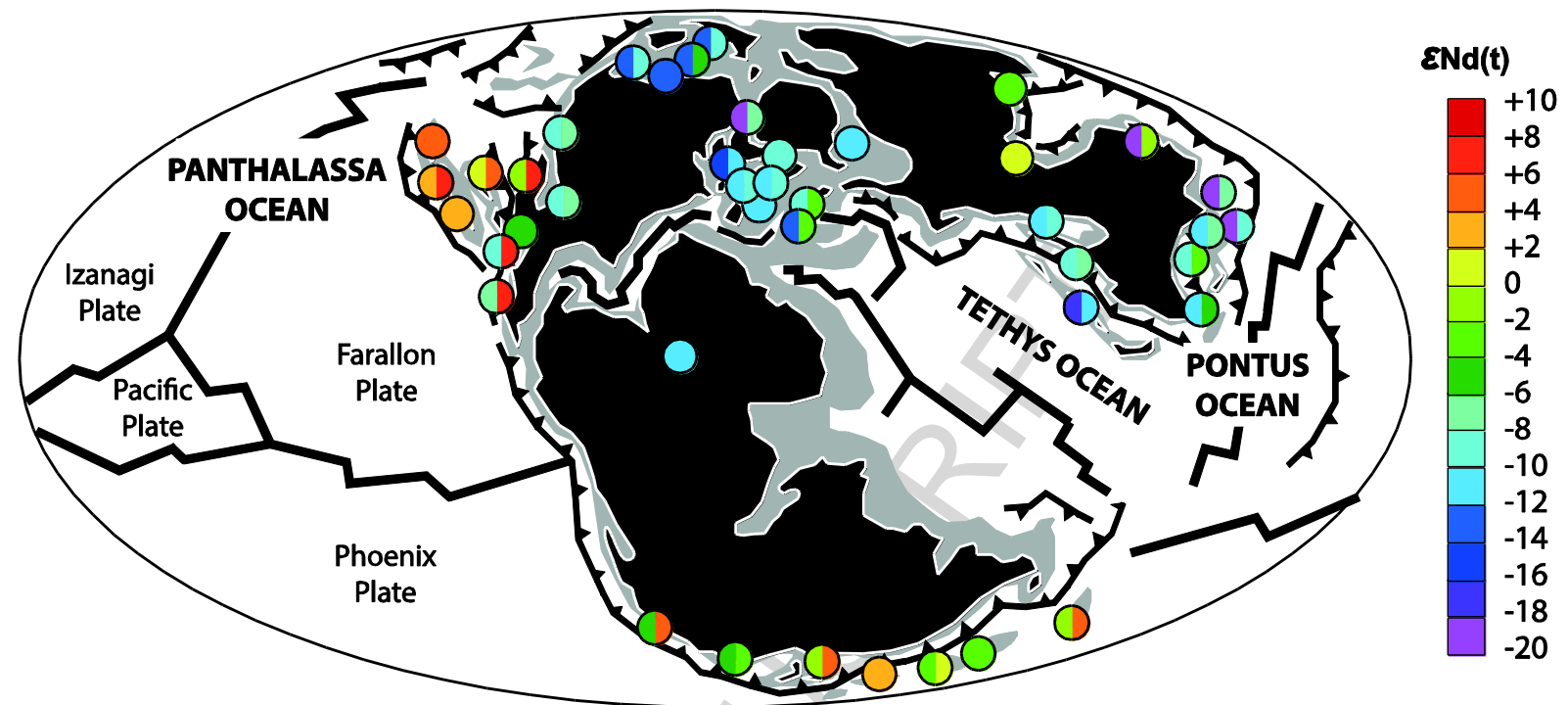

Fig 4 
Age (Ma)

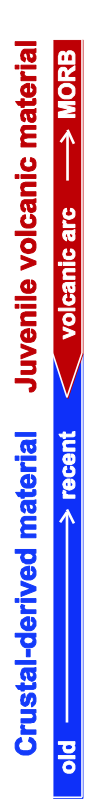

$\begin{array}{llllllllllll}205 & 200 & 195 & 190 & 185 & 180 & 175 & 170 & 165 & 160 & 155 & 150\end{array}$

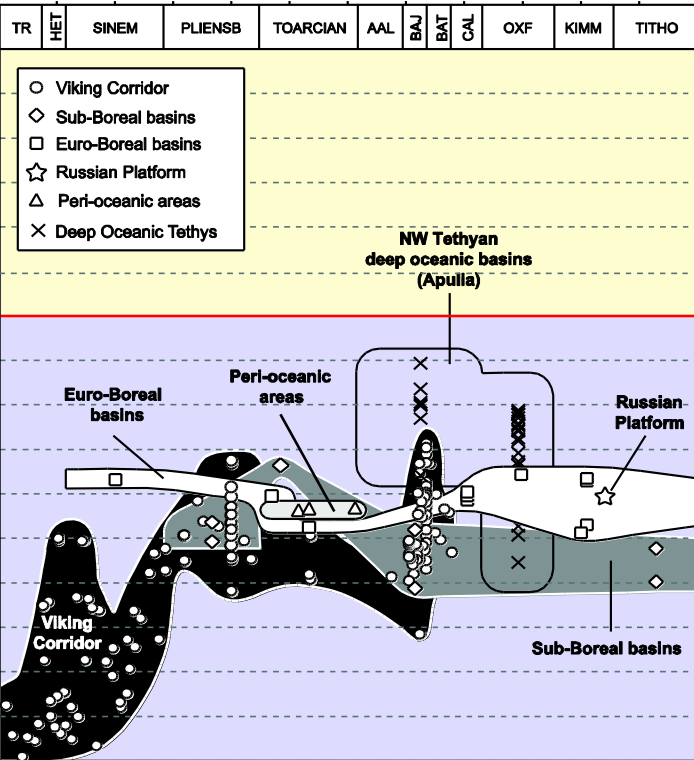

A - North West of Tethys

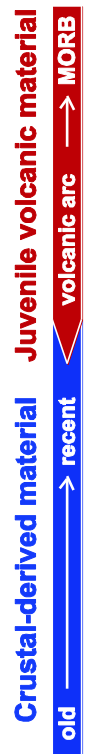

$\begin{array}{llllllllllll}205 & 200 & 195 & 190 & 185 & 180 & 175 & 170 & 165 & 160 & 155 & 150\end{array}$

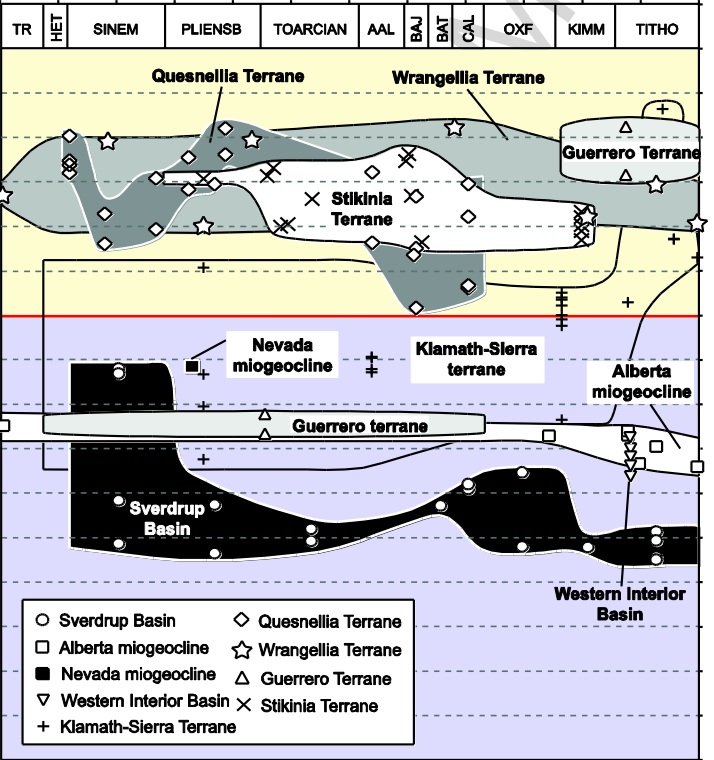

C - Arctic and American Panthalassa
Age (Ma)

$\begin{array}{llllllllllll}205 & 200 & 195 & 190 & 185 & 180 & 175 & 170 & 165 & 160 & 155 & 150\end{array}$

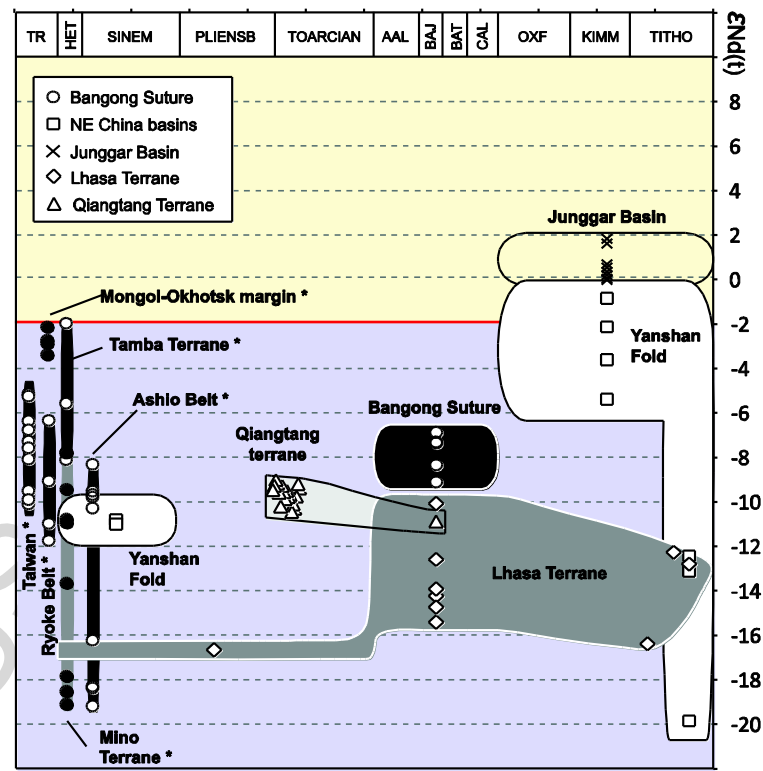

B - Amuria / Asian terranes

$\begin{array}{llllllllllll}205 & 200 & 195 & 190 & 185 & 180 & 175 & 170 & 165 & 160 & 155 & 150\end{array}$

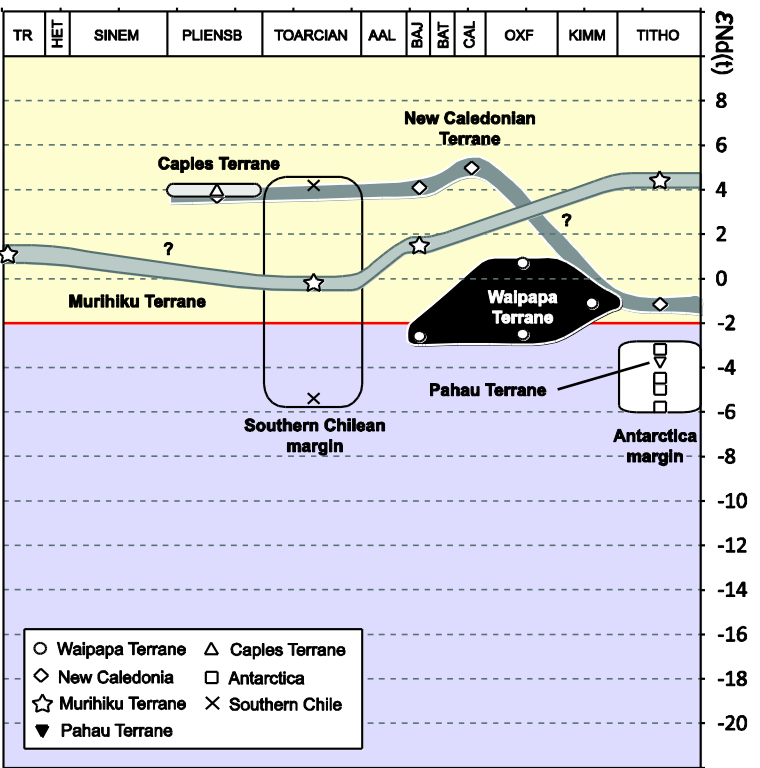

D - Southern Gondwana

Fig 5 


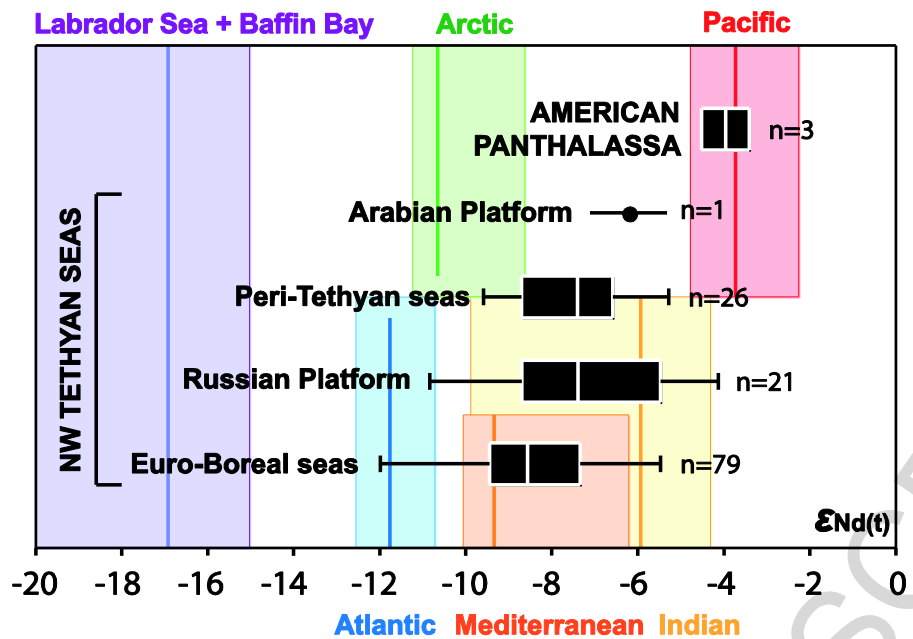

Fig 6 


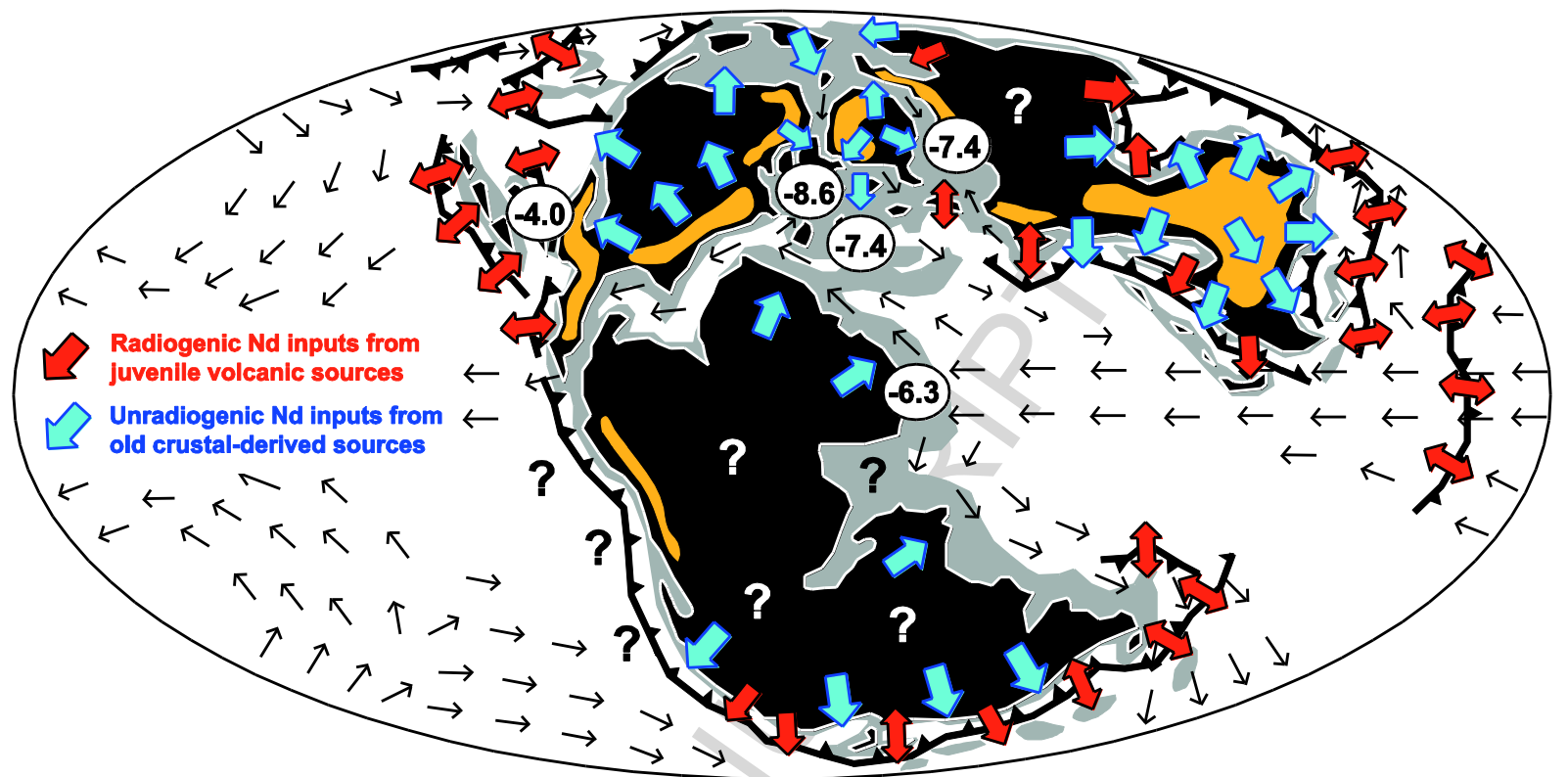

Fig 7 


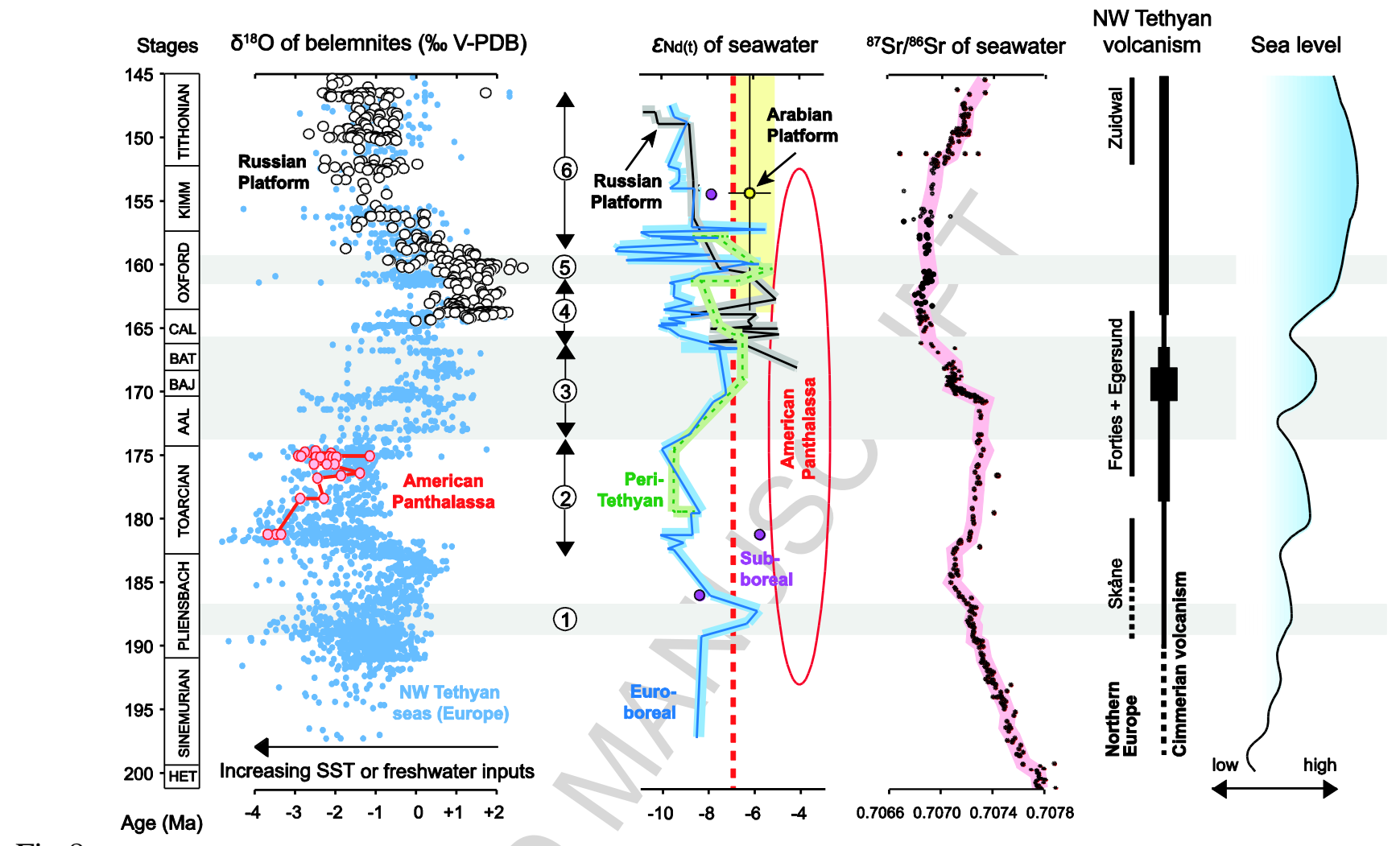

Fig 8 


\begin{tabular}{|c|c|c|c|c|c|c|c|c|c|}
\hline $\begin{array}{l}\text { Basi } \\
\text { n }\end{array}$ & Location & Stage & $\begin{array}{l}\text { Biozone } \\
\text { (subzone) }\end{array}$ & $\begin{array}{l}\text { Age } \\
(\mathrm{Ma}) \\
\end{array}$ & $\begin{array}{l}\text { [Nd] } \\
\text { ppm }\end{array}$ & $\begin{array}{l}\text { [Sm] } \\
\text { ppm }\end{array}$ & $\begin{array}{c}{ }^{143} \mathrm{Nd} / /^{144} \\
\mathrm{Nd}\end{array}$ & $\begin{array}{c}{ }^{147} \mathrm{Sm} /{ }^{14} \\
{ }^{4} \mathrm{Nd} \\
\end{array}$ & $\begin{array}{c}\varepsilon_{\mathrm{Nd}(\mathrm{t}} \\
\mathrm{I}\end{array}$ \\
\hline SB & Holzmaden, Germany & E. Toarcian & $\begin{array}{l}\text { tenuicostatum- } \\
\text { falciferum }\end{array}$ & $\begin{array}{c}181.65 \\
0\end{array}$ & 1860 & 523.2 & $\begin{array}{c}0.512144 \\
\pm 4\end{array}$ & 0.170153 & $\begin{array}{c}- \\
9.02 \\
-\end{array}$ \\
\hline SB & Holzmaden, Germany & E. Toarcian & $\begin{array}{l}\text { tenuicostatum- } \\
\text { falciferum }\end{array}$ & $\begin{array}{c}0 \\
181.02\end{array}$ & 16.36 & 3.526 & $\begin{array}{c}0.512041 \\
\pm 5 \\
0.512164\end{array}$ & 0.130371 & $\begin{array}{c}10.1 \\
1 \\
-\end{array}$ \\
\hline SB & Holzmaden, Germany & E. Toarcian & falciferum & $\begin{array}{c}5 \\
163.62\end{array}$ & 2410.2 & 679.5 & $\begin{array}{c} \pm 7 \\
0.512153\end{array}$ & 0.170538 & $\begin{array}{c}8.64 \\
-\end{array}$ \\
\hline SB & Reutlingen, Germany & L. Callovian & lamberti & $\begin{array}{c}5 \\
157.65\end{array}$ & 383.4 & 78.48 & $\begin{array}{c} \pm 5 \\
0.512189\end{array}$ & 0.123820 & $\begin{array}{c}7.95 \\
-\end{array}$ \\
\hline SB & Buchsteige, Germany & $\begin{array}{l}\text { L. Oxfordian } \\
\text { U. }\end{array}$ & bimammatum & 0 & 741.2 & 166.2 & \pm 8 & 0.135637 & 7.54 \\
\hline $\begin{array}{l}\text { BO } \\
\text { NW }\end{array}$ & Bornholm, Denmark & $\begin{array}{l}\text { Pliensbachia } \\
\mathrm{n}\end{array}$ & margaritatus & $\begin{array}{c}185.80 \\
0 \\
181.02\end{array}$ & 240.16 & 53.69 & $\begin{array}{c}0.512132 \\
\pm 6 \\
0.512295\end{array}$ & 0.135228 & $\begin{array}{c}- \\
8.41 \\
-\end{array}$ \\
\hline $\begin{array}{l}\text { GB } \\
\text { NW }\end{array}$ & Schandelah, Germany & E. Toarcian & elegantulum & $\begin{array}{c}5 \\
181.02\end{array}$ & 18.357 & 4.794 & $\begin{array}{c} \pm 8 \\
0.512095\end{array}$ & 0.157972 & 5.79 \\
\hline GB & Schandelah, Germany & $\begin{array}{l}\text { E. Toarcian } \\
\text { L. }\end{array}$ & elegantulum & 5 & 5.72 & 1.084 & \pm 10 & 0.114635 & -8.7 \\
\hline NW & & Kimmeridgi & & 154.25 & & & 0.512168 & & - \\
\hline GB & Goslar, Germany & an $\circlearrowleft$ & mutabilis? & $\begin{array}{c}0 \\
164.35\end{array}$ & 617.7 & 135.12 & $\begin{array}{c} \pm 3 \\
0.512109\end{array}$ & 0.132320 & $\begin{array}{c}7.91 \\
-\end{array}$ \\
\hline WB & Rookery pit, Stewartby, England & M. Callovian & coronatum & 0 & 78.06 & 17.163 & \pm 9 & 0.132999 & $\begin{array}{c}9.00 \\
-\end{array}$ \\
\hline WB & Rookery pit, Stewartby, England & M. Callovian & jason (medea) & $\begin{array}{c}164.55 \\
0 \\
182.17\end{array}$ & 352.5 & 73.59 & $\begin{array}{c}0.512043 \\
\pm 4 \\
0.512040\end{array}$ & 0.126283 & $\begin{array}{c}10.1 \\
5 \\
-\end{array}$ \\
\hline PB & Chaumitton, France & E. Toarcian & tenuicostatum? & $\begin{array}{c}5 \\
173.10\end{array}$ & 1511.4 & 254.58 & $\begin{array}{c} \pm 4 \\
0.512151\end{array}$ & 0.101889 & $\begin{array}{c}9.46 \\
-\end{array}$ \\
\hline PB & Feugueurolle, France & E. Aalenian & opalinum & $\begin{array}{c}0 \\
170.55\end{array}$ & 72.78 & 19.647 & $\begin{array}{c} \pm 7 \\
0.512190\end{array}$ & 0.163293 & $\begin{array}{c}8.76 \\
-\end{array}$ \\
\hline PB & Rumelange, Luxembourg & L. Aalenian & concavum & 0 & 2293.8 & 571.2 & \pm 4 & 0.150632 & 7.73 \\
\hline PB & Rumelange, Luxembourg & E. Bajocian & discites (walkeri) & 170.20 & 2836.8 & 631.8 & 0.512190 & 0.134721 & -7.4 \\
\hline
\end{tabular}


PB Feugueurolle, France

PB Rumelange, Luxembourg

PB Boulogne, France

PB Wimereux, France

RP Sokur, Saratov region, Russia

RP Sokur, Saratov region, Russia Mikhalenino, Kostroma region,

RP Russia

Mikhalenino, Kostroma region,

RP Russia

Mihajlovskij Rudnik, Kursk region,

RP Russia

RP Fokino, Bryansk region, Russia

RP TĖC-5, Saratov region, Russia Mihajlovskij Rudnik, Kursk region,

RP Russia

RP Neelovka, Saratov region, Russia Khlebnovka, Saratov region,

RP Russia

RP Dubki, Saratov region, Russia

RP Dubki, Saratov region, Russia

RP Dubki, Saratov region, Russia RP Mikhalenino, Kostroma region,
E. Bajocian laeviscula

E. Bajocian humphresianum

Kimmeridgi eudoxus

an (caletanum)

L. Tithonian -

E.

Bathonian ishmae

E.

Bathonian ishmae

E. Callovian elatmae

E. Callovian elatmae

koenigi

E. Callovian (indigestus)

E. Callovian calloviense

E. Callovian calloviense

E. Callovian calloviense

M. Callovian jason

L. Callovian athleta-spinosum lamberti

L. Callovian (mojarowskii)

L. Callovian lamberti

E.

Oxfordian mariae

M. densiplicatum
0

169.95

169.50

0

6.582

$2458.2 \quad 559.8$$$
\pm 4
$$

0.512190

\pm 5
0.512203

$\pm 5$

$0.124967 \quad 7.19$

153.12

5

147.25

0

167.82

5
67.82

167.82

165.80

0
65.80

165.80

0

165.20

0

164.75

0

164.75

0

164.75

0

164.55

0
64.00

164.00

0

163.62

5
163.62

5

162.45

0

160.40

$734.1 \quad 127.5$

0.512107

$$
\pm 7
$$

0.512057

$\pm 5$

0.512374

$\pm 5$

$248.91 \quad 62.04$

0.512368

$73.38 \quad 17.4$

$\pm 7$

0.512250

$639.6 \quad 164.01$

$\pm 4$

0.512253

$885.6 \quad 317.1$

$\pm 5$

$12.948 \quad 1.9338$

399

183.9

104.55

0.512271

$\pm 4$

0.512192

$\pm 7$

0.512226

$\pm 6$

0.512258

$\pm 4$

$11.199 \quad 1.503$

0.512256

$63.69 \quad 13.866$

$\pm 7$

0.512279

$179.07 \quad 47.82$

$\pm 5$

$5.805 \quad 1.23$

0.512262

$\pm 4$

0.512122

$\pm 5$

$126.18 \quad 27.819$

$6.384 \quad 1.378$

0.512309

$\pm 6$

$8.256 \quad 0.978$

0.512185

$0.137752 \quad 7.21$

$0.105060 \quad 8.57$

$0.106125 \quad 9.65$

$0.150769 \quad 4.17$

$0.143435 \quad 4.13$

$0.155112-6.7$

0.2165927 .93

$0.090343 \quad 4.93$

$0.158502-7.9$

$0.165977 \quad-7.4$

$0.081183 \quad 5.00$

$0.131693-6.1$

$0.161536 \quad 6.28$

$0.128170 \quad 5.92$

$0.133363 \quad 8.76$

$0.130569 \quad 5.07$

0.071656 
Russia

Northern Makariev, Kostroma

RP

region, Russia

Mikhalenino, Kostroma region,

RP Russia

Gorodischi, Ul'yanovsk region,

RP Russia

Gorodischi, Ul'yanovsk region,

RP Russia

Gorodischi, UI'yanovsk region,

RP Russia

RP Ivkino, Kostroma region, Russia

RP Kuntsevo, Moscow, Russia

RP Kuntsevo, Moscow, Russia

SEB Belmont d'Azergues, France

SEB Belmont d'Azergues, France

SEB Belmont d'Azergues, France

SEB Belmont d'Azergues, France

SEB Belmont d'Azergues, France

SEB Belmont d'Azergues, France

WT Kennecott point, Graham Island,
Oxfordian

$M$.

Oxfordian

E.

Kimmeridgi

an unknown

Kimmeridgi

an

Kimmeridgi

an

eudoxus?-

autissiodorensi

eudoxus?-

autissiodorensi

M. Volgian panderi

M. Volgian

panderi

M. Volgian

virgatus-nikitini

M. Volgian virgatus-nikitini

M. Toarcian bifrons

M. Toarcian bifrons

M. Toarcian bifrons

M. Toarcian bifrons

M. Toarcian bifrons

pseudoradiosa-

L. Toarcian aalensis

E.
0

160.00

0

156.00

0

153.12

5

153.12

5

148.65

0

148.65

0
147.70

0

147.70

0

179.30

0

179.30

0

179.30

0

179.30

0

179.30

0

174.40

0

198.50

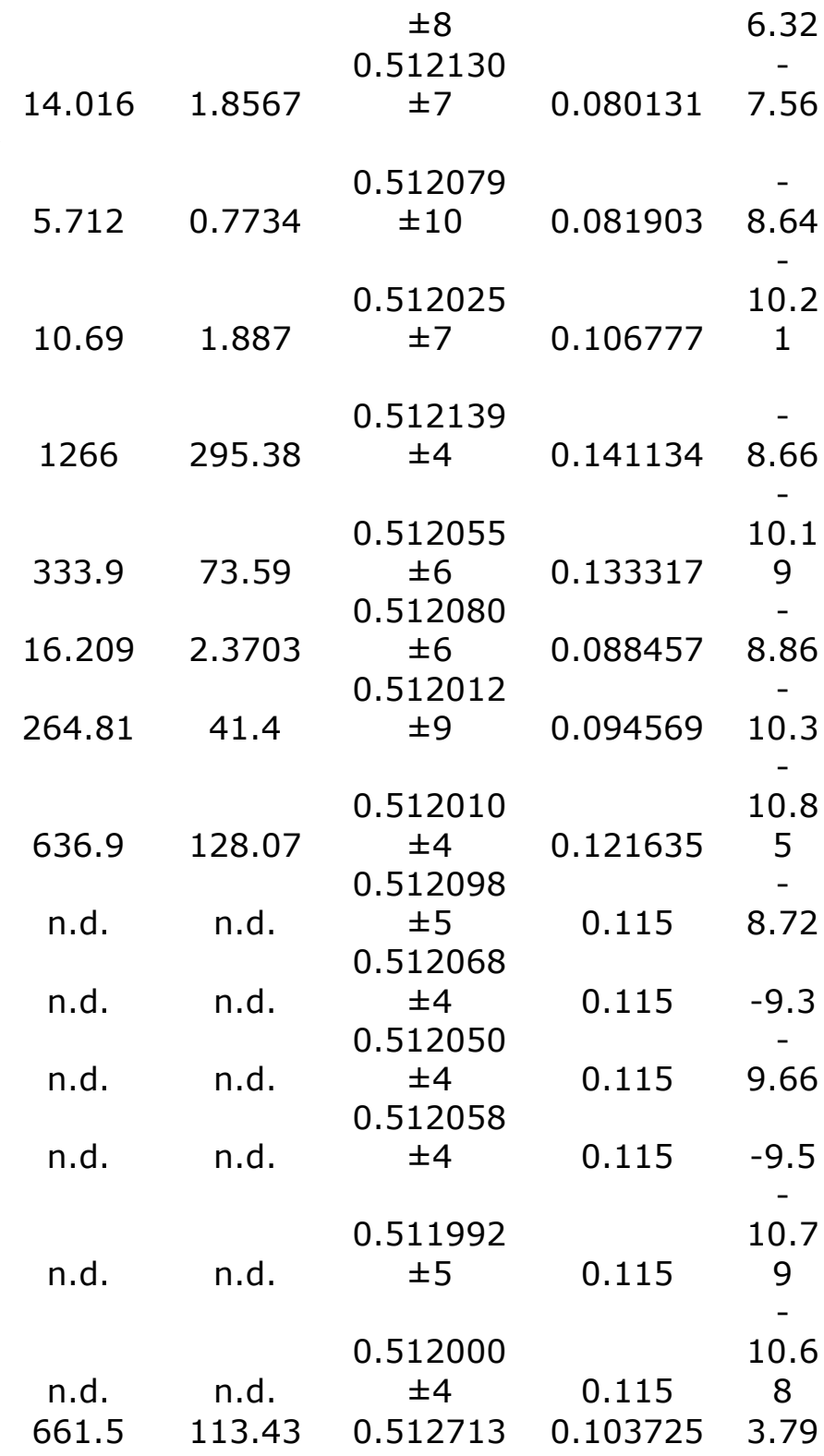


Canada

Yakoun river, Queen Charlotte

Islands, Canada

PT Alaska, USA

PT Alaska, USA

Clan Alpine mountains, Nevada,

ACM USA

Clan Alpine mountains, Nevada, ACM USA

$\begin{array}{ll}\text { Sinemurian } & \text { (bucklandi) } \\ \text { E. Toarcian } & \text { kanense } \\ \text { L. } & \\ \text { Pliensbachia } & \\ \mathrm{n} & \text { carlottense } \\ \text { L. } & \\ \text { Pliensbachia } & \\ \mathrm{n} & \text { carlottense } \\ \text { E. } & \\ \text { Pliensbachia } & \\ \mathrm{n} & \text { freboldi } \\ \text { E. } & \\ \text { Pliensbachia } & \\ \mathrm{n} & \text { freboldi }\end{array}$

\begin{tabular}{|c|c|c|c|c|c|}
\hline 0 & & & \pm 5 & & \\
\hline 181.50 & & & 0.512727 & & \\
\hline 0 & 63.06 & 14.103 & \pm 3 & 0.135282 & 3.17 \\
\hline $\begin{array}{l}83.40 \\
0\end{array}$ & 10.107 & 2.307 & $\begin{array}{c}0.513012 \\
\pm 6\end{array}$ & 0.138073 & 8.68 \\
\hline $\begin{array}{c}183.40 \\
0\end{array}$ & 12.065 & 3.3915 & $\begin{array}{c}0.512911 \\
\pm 6\end{array}$ & 0.170039 & 5.95 \\
\hline $\begin{array}{c}188.00 \\
0\end{array}$ & n.d. & n.d. & $\begin{array}{c}0.512367 \\
\pm 9\end{array}$ & 0.115 & -3.4 \\
\hline $\begin{array}{c}188.00 \\
0\end{array}$ & 214.7 & 48.04 & $\begin{array}{c}0.512339 \\
\pm 7\end{array}$ & 0.135349 & 4.37 \\
\hline
\end{tabular}




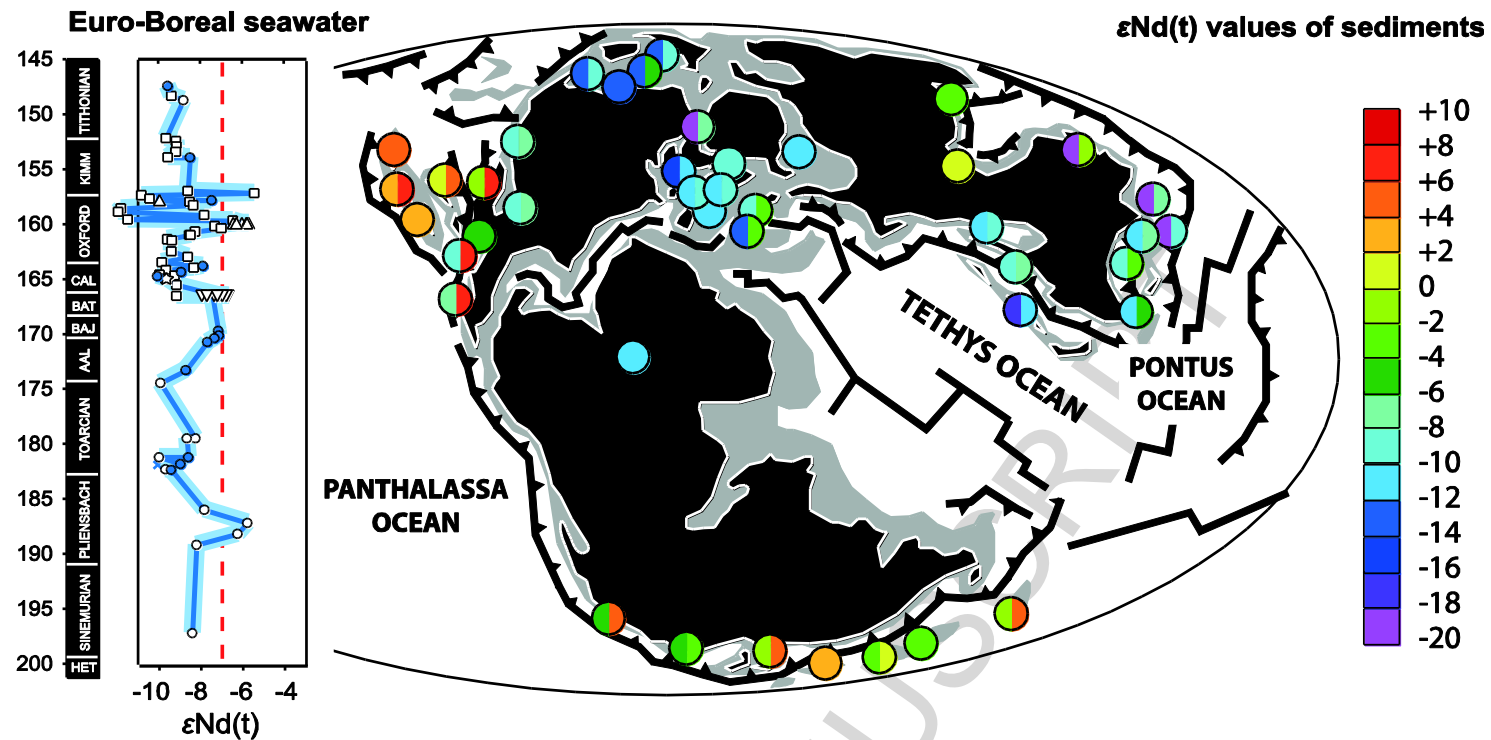

Graphical abstract 
Highlights

- The continental sources of $\mathrm{Nd}$ were heterogeneous during the Jurassic

- Numerous changes in the $\mathrm{Nd}$ isotope composition of oceans and sediments are recorded

- Changes reflect oceanic, climatic, and volcanic events related to the Pangean breakup 